\title{
Espacios, lugares e imágenes en la construcción biográfica. El maestro Clemente Antonio Neve durante la época de Maximiliano
}

\author{
MÍLADA BAZANT
}

\begin{abstract}
El objetivo de este trabajo es presentar un ejercicio metodológico acerca del recorrido que puede realizar el biógrafo en el macro, medio y microespacio para conocer los mapas culturales de su biografiado. Intento elaborar una "historización" del espacio, es decir, estudiar mediante diversos tipos de imágenes el espacio urbano y rural, individual y colectivo, en sus aspectos físicos y sociales. Cuando una persona o un grupo social se apropia de un espacio, le atribuye un significado, entonces se convierte en "lugar" y pone de manifiesto una práctica cotidiana.
\end{abstract}

PalABRAS ClaVE: imágenes, espacio, biografía, Maximiliano, Neve

Spaces, Places and Images in the Biographical Construction. Clemente Antonio Neve During the Time of Maximilian

The article's goal is to present a methodological exercise in studying the macro, medium and micro space which a biographer can use to get to know the cultural maps of a person in question. My purpose is to "historicize" space, that is to say, study the different types of images, urban and rural space, and physical and social aspects of the individual and the collective. The appropriation of spaces by a person or a social group gives it a meaning and turns "space" into an everyday practice.

KEYWORDS: images, space, biography, Maximiliano, Neve 
n este trabajo haré una reflexión en torno a los espacios que recorre el biógrafo para conocer el paisaje cultural que acompaña a su biografiado a lo largo de su vida. El biógrafo-flâneur transita por los espacios íntimo, familiar, urbano, rural, natural, artístico y todos aquellos donde vive su biografiado a diario, puesto que le ofrecen un abanico de posibilidades creativas. Entiendo por "cotidiano" la rutina del día a día, aquello que es experiencia peculiar en un ser humano, su jornada laboral y su vida doméstica, sus costumbres habituales (Gonzalbo, 2006: 26-27).

Como el espacio es un concepto "abstracto e indiferenciado" (Tuan, 2011: 6), inmenso, disperso, "desmedido" (Rilke, citado en Bachelard, 1993: 269), propongo un esquema analítico que divide los espacios cotidianos en macro, mezzo — medio o intermedio- - y micro, ${ }^{1}$ porque considero que así se comprenden mejor sus características dimensionales y pueden relacionarse "escenográficamente" con momentos en la vida del biografiado. También busco establecer la diferencia entre espacio y lugar como conceptos del quehacer biográfico. Insisto en el uso del apelativo flâneur porque todos los paseos que realiza el biógrafo deben ser lentos, su actitud debe ser de curiosidad y asombro ante lo que está en la superficie y detrás de lo visto.

En el campo de la biografía, entiendo el espacio y el lugar como los escenarios posibles en los cuales el protagonista transita de manera estática o dinámica por una sucesión cronológica o causal de acontecimientos. Por otra parte, al analizar la vida de mi biografiado, mantengo una mirada transdisciplinaria que contempla el paralelismo entre las perspectivas del espacio geográfico y la temporalidad histórica. En este aspecto, me apoyo en el nuevo enfoque, The Spatial Turn, ${ }^{2}$ con el

1 Edward Soja menciona el macro y el microespacio y encuentra entre éstos un espacio intermedio al que llama mezzo o medio. Soja es geógrafo urbanista y "mira las ciudades bajo la perspectiva macro-mezzo-micro" (Tomàs, 2004). Aplico estos conceptos a la biografía.

2 Henri Lefebvre y Michel Foucault fueron las figuras iniciales y más importantes de este movimiento radical de pensamiento, acerca de las relaciones ontológicas, epistemológicas y teóricas de tiempo y espacio (Soja, 2009: 18). The Spatial Turn irrumpió en el medio académico en la década de 1990. 
cual se intenta desarrollar una manera más creativa de imaginar dicha perspectiva (Soja, 2009: 12). Enmarcada en la creencia de que los apuntes autobiográficos, las biografías, las vidas de los seres humanos son tan "geográficos" como "históricos", la nueva corriente se dirige hacia un nuevo paradigma que contempla una triple dialéctica entre la imaginación histórico-temporal, la geográfico-espacial y la sociológico-social. Estas variables desarrollan un movimiento triléctico entre ellas y ninguna ejerce mayor fuerza sobre las otras (Soja, 2009: 12-22). Así, de acuerdo con Lefebvre, recorro con mi protagonista Clemente Antonio Neve (1820-1904) sus espaces vécus, sus espacios experimentados, ${ }^{3}$ a la luz y sombra de un momento y lugar determinados durante la época de Maximiliano (Soja, 2009: 19; Baringo, 2013: 124).

Creo que es difícil, si no imposible, imaginar la vida de Clemente Antonio Neve si no se conocen los caminos que recorrió, los ríos que atravesó, los paisajes que vio, las casas donde vivió. Por ello, para adentrarme en el ritmo cotidiano de la historia y de $s u$ historia, utilizo diversos tipos de imágenes que ejemplifican el ejercicio metodológico llevado a cabo con los recorridos que realizó mi protagonista, maestro rural indígena y autor de varios textos y métodos escolares, quien alcanzó la gloria de su carrera docente durante la época de Maximiliano. En este trabajo me abocaré a relatar algunos episodios de su vida durante los años del Segundo Imperio. Mi objetivo es fomentar la imaginación y transmitir con riqueza narrativa las vivencias del maestro, para así conocer las características de la educación popular por medio de la historia de un docente conflictivo, pero destacado y perfeccionista. Para la reconstrucción de la historia de este profesor, no sólo propongo el empleo de fuentes textuales sino también visuales, como, por ejemplo, del paisajismo mexicano, pues este terreno ha sido poco explorado en la historiografía y sirve de telón de fondo.

\section{La experiencia perceptual de espacio y lugar}

Dada la cantidad y variedad de información que como personas captamos en nuestra vida cotidiana y a lo largo de nuestra existencia, es necesario comenzar por el proceso de vinculación con lo que nos rodea. En cualquier situación, primero percibimos con los sentidos y luego procesamos la información racionalmente. Primero oímos una voz y luego procesamos de quién es y de dónde viene. Percibimos de lo general a lo particular: primero el paisaje en su plenitud, luego las flores a nuestros pies; primero una plaza majestuosa, después las edificaciones y las personas que pasan. Asimismo, al entrar en una casa, primero observamos los espacios generales, luego nos introducimos en un cuarto determinado, miramos los muebles y luego los objetos. Es un proceso interactivo que va de lo sensorial a lo racional, pasa por lo emotivo y regresa para afinar nuestra percepción. Transita de lo general al detalle y vuelve a lo general para precisar detalles. Cada persona le da un tinte diferente a la percepción de una realidad: algunos son más sensibles que racionales, otros ven más el conjunto que los detalles. Una misma realidad puede ser vivida y experimentada de múltiples maneras.

Sabemos que la geografía es una aliada de la historia y que el biógrafo-historiador jugará con celeridad o parsimonia con el tiempo-espacio de su sujeto, según la caligrafía de sus sueños y artificios. La vida del biografiado es un devenir en el tiempo, está circunscrita a un espacio, a una envolvente físicoespacial dentro de la cual el personaje está inmerso. La envolvente se convierte en "lugar" cuando empezamos a conocerlo y le atribuimos un valor. La personalización y el conocimiento de un espacio, por medio de la investigación del biógrafo respecto a su biografiado, lo convierte en lugar paulatinamente.

El espacio experimentado supera al espacio físico, ya que la gente hace uso simbólico de los objetos que lo componen (Baringo, 2013: 124). 
El espacio nos proporciona libertad; el lugar, seguridad (Tuan, 2011: 6). En un proceso dialéctico entre el cobijo de uno y la aventura del otro, el ser humano deambula entre los dos (Tuan, 2011: 54). El espacio es libre, como un lienzo en blanco, es decir, lleno de posibilidades que se van dibujando con la información e interpretación de los contextos en los que transcurrió la vida del biografiado. Al otorgarle valor al espacio, al hacerlo específico, se convierte en lugar.

Existe un momento en el quehacer del biógrafo que representa un punto de transición entre el espacio y el lugar. Denomino "espacio-lugar" a este tránsito durante el cual el biógrafo recorre de nuevo los entornos en los que sucedieron los eventos de la vida del biografiado. En el espacio-lugar las dos temporalidades se traslapan - la del biógrafo y la del biografiado- - y empiezan a formarse vínculos racionales, sensoriales y emocionales entre el objeto de estudio y el sujeto que lo estudia.

El espacio-lugar es un vínculo mental y emocional que puede detonarse por medio del paisaje, la plaza o la habitación con los que está relacionado el biografiado; es un vínculo que está al centro de cada escena pero que es reconstruido por el biógrafo. Todo va fluyendo en el tiempo: el biografiado también envejece lentamente y cambia al igual que todo lo que lo rodea. Nada es estático, todo se hilvana en cambios sucesivos que a veces son sutiles, y en ocasiones, violentos.

\section{Las imágenes}

\section{LAS PINTURAS Y LAS PALABRAS}

En los últimos años, se ha hecho más frecuente el uso de imágenes en los estudios históricos. Por lo general, los historiadores las utilizan como mero recurso ilustrativo, no como una fuente histórica que es necesario interpretar. Historiadores e historiadores del arte siguen varios principios para observar una imagen: los primeros buscan la evidencia más allá de la imagen y los segundos analizan tanto la imagen en sí como a sus artífices. Ambos pueden converger en sus enfoques y muchas veces sus disciplinas diluyen sus diferencias (Rotberg y Rabb, 1988: 1). Las palabras pueden ser tan evasivas como las pinturas y su veracidad es frágil. No obstante, es lugar común aceptar que para la mayoría de los estudiosos lo textual mantiene, hasta la fecha, un lugar prioritario. Pese a ello, también están de acuerdo en que pintores, escultores y arquitectos nos dan claves para entender el universo que habitaron, que no existen en ninguna otra fuente (Rotberg y Rabb, 1988: 2).

De acuerdo con el estudio sobre la historia medieval otoñal de Johan Huizinga, las imágenes reflejan una realidad idealizada, pues las obras pictóricas debían ser bellas "porque su asunto era santo o su destino elevado" (Huizinga, 1984: 357). Sin embargo, la "realidad real" retrataba "una sucesión continua de mala administración y rapacidad, guerras y latrocinios, carestía, miseria y pestilencias" (Huizinga, 1984: 43). El historiador holandés se cuestiona si las artes plásticas dejan tras de sí una imagen de los tiempos más serena que la palabra de los poetas o de los historiadores (Huizinga, 1984: 355). Deslumbrado con el arte plástico de los hermanos Van Eyck, una de sus principales fuentes, su respuesta es larga y erudita: en comparación con la riqueza del genio del detalle, la perspectiva, la línea y el color, sobre todo de Jan Van Eyck, que logra captar el espíritu de una época, la literatura es pobre y aburrida. ${ }^{4} \mathrm{El}$ poeta puede colorear la realidad que ve y que piensa, pero no surge de él una línea nueva (Huizinga, 1984: 406); por el contrario, la prosa logra

Para tener elementos contundentes de análisis, Huizinga compara "las mismas materias que manan de las mismas fuentes, que proceden de la misma esfera de la vida" y ésta es la esfera de las fastuosas cortes de los príncipes y la rica burguesía. "La literatura que se encuentra en la misma línea que el arte de Van Eyck es la literatura áulica, o al menos aristocrática, escrita en lengua francesa y admirada por los círculos que encargaban sus obras a los grandes pintores" (Huizinga, 1984: 399). 
igualar "aunque sea en lo menos" a Van Eyck. ${ }^{5}$ En suma, como han advertido varios estudiosos, la imagen embelesa más al estudioso del pasado porque le llega directo a los sentidos. En cambio, la palabra navega en el terreno del intelecto. Bien decía Gustave Flaubert, quien siempre se negó a que su obra fuera acompañada con imágenes: "Nadie me ilustrará mientras yo viva ya que el más ínfimo dibujo devora la más hermosa descripción literaria” (Manguel, 2002: 20).

Sea como fuere, no hay duda de que las imágenes nos ayudan a imaginar el pasado de manera más viva (Burke, 2005: 16). En la elaboración de esta biografía sobre el maestro rural Clemente Antonio Neve me he propuesto utilizar una gama de recursos mayor, y sobre todo más variada, que me ayude, por ejemplo, a oler los aromas, a degustar los sabores, a escuchar los sonidos y ruidos, a ver los paisajes rurales y citadinos y a tocar ese pasado en el cual mi biografiado estaba vivo; a acercarme lo más posible a lo que fue, o como dice Pérez Vejo, a cómo se imaginaron su mundo Neve y sus contemporáneos (2012: 27-29).

En el caso de Clemente Antonio Neve, maestro rural, existen tan pocos registros escritos sobre su vida personal que es necesario hacer uso de la mayor cantidad disponible de información. No aprovechar la cultura material de la época, como mapas, pinturas, utensilios, arquitectura, etc., para reconstruir su historia, resultaría una pérdida, pues obstaculizaría el posible conocimiento de la vida de sujetos "comunes y corrientes" que, como él, no formaban parte de la clase dominante — en este caso, municipal- y acerca de los cuales existen pocas fuentes escritas. Mi propósito es retratar el contexto de la empobrecida y compleja vida cotidiana rural de la segunda mitad del siglo XIX.

\section{LOS MAPAS}

Una de las medidas que tomaron los gobiernos mexicanos a lo largo del siglo XIX de forma prioritaria fue establecer rutinas cartográficas con el objetivo de conocer el territorio nacional: el nombre de las poblaciones, el número de habitantes, la diversidad de los recursos. La finalidad era identificar y asumir el control de los espacios, de la riqueza y de la gente, y constituir la deseada moderna nación mexicana. La cartografía de la época se fundaba en los mismos principios geométricos y matemáticos del espacio en perspectiva y había tomado forma como ciencia “objetiva" al mediar entre la realidad espacial y la percepción humana de esa realidad (Craib, 2004: 6-7). Esta labor, indispensable para conocer de manera detallada el territorio mexicano, llegó a su plenitud durante el porfiriato. El general Díaz encomendó a los supervisores un mapa "perfecto" de la república, solicitó información a las autoridades estatales y municipales y tomó como base la primera Carta General de la República Mexicana elaborada en 1858 por Antonio García Cubas (Craib, 2004: 14-15).

García Cubas unió todos los mapas existentes y los "coordinó" mediante la superposición de la gratícula, red imaginaria de paralelos y meridianos que envuelven el globo terráqueo y proveen las coordenadas geográficas. Por primera vez, García Cubas posicionó a México en el meridiano de Greenwich y no en la catedral de la ciudad de México, meridiano tradicional en los mapas mexicanos. Así, llevó al país a la cartografía de la época, como se realizaba en los países civilizados, lo que le atribuyó una sensibilidad espacial moderna (Craib, 2004: 33).

Sólo la égloga, la burla en literatura, logra captar también el espíritu de la época (Huizinga, 1984: 17-19). Huizinga utilizó un buen número de fuentes históricas, entre ellas, la que teje el libro Oeurres de Georges Chastellain (14051475), poeta, literato, cronista y escudero; sus obras, en ocho volúmenes, fueron publicadas entre 1863 y 1866. Sin embargo, asienta que si bien entre Chastellain y Jan Van Eyck "existe una innegable afinidad, con una gran diferencia de nivel artístico. Lo mejor de Chastellain corresponde, en el caso más favorable, a lo menos bueno de Van Eyck" (Huizinga, 1984: 410). 
En la Mapoteca "Manuel Orozco y Berra" se conserva una gran cantidad de mapas del siglo XIX, tanto urbanos como rurales. Estos mapas me ayudaron a recorrer los caminos carreteros, de travesía, principales y veredas por los cuales transitó Clemente Antonio Neve al mismo tiempo que contemplaba los campos de maíz, trigo y cebada, los montes, bosques y ríos, observables también en los mapas.

\section{EL PAISAJE “ABARCADOR”}

El Ensayo político sobre el reino de la Nueva España, de Alexander von Humboldt, y la política mexicana de colonización, que prometía terrenos y exención de impuestos, motivaron que viajeros, científicos, diplomáticos, comerciantes y empresarios vinieran a México en busca de aventura, fortuna, negocios y placer. Entre ellos, llegaron artistas con una enorme capacidad de adaptación a un medio ambiente disímil, muchas veces adverso en clima, costumbres e idioma (Diener, 1996: 63), y gran curiosidad por conocer el nuevo mundo tropical y fecundo. Herederos de la tradición ilustrada, muchos de ellos habían leído el Cosmos, de Humboldt, en el que éste afirmaba que el campo del arte era un auxiliar de las ciencias. Este subgénero del artista-científico debía captar la "fisonomía del paisaje", incluir en el lienzo el clima, la historia, la fauna, la flora, los vientos, la quietud (Aira, 2002: 10). En suma, interpretar el paisaje de manera global, el paisaje abarcador. Más que pensar en los paisajes como los concebimos ahora, aquellos artistas pretendían plasmar "representaciones de carácter descriptivo en el sentido que introdujo la Ilustración de un espacio determinado" (Debroise, 1989: 104), es decir, vistas topográficas que representaran formas y espacios que imperaban sobre la interpretación subjetiva (Chevrier, citado en Debroise, 1989: 104).

Entre los más destacados están Rugendas, Egerton, Gros y Gualdi (Von Wobeser, 1989: 184), que nos legaron evidencias de cómo era el paisaje mexicano. En México, la pintura de paisaje era considerada un género menor, de modo que no había paisajistas mexicanos. Esto cambiaría en 1850, cuando llegó a la Academia de Artes, invitado por el gobierno mexicano, el italiano Eugenio Landesio a enseñar precisamente técnica de paisaje y perspectiva. Su alumno más destacado sería Velasco, quien, también influido por la cartografía moderna, plasmaría en algunos de sus lienzos el rostro no sólo de una ciudad, sino de una ciudad que se ve como un mapa por la forma en que concibió el paisaje urbano (Gandelman, 1989: 100-101). Todos estos paisajes me ayudaron a imaginar la hermosa naturaleza urbana y rural del siglo XIX.

\section{LITOGRAFÍAS Y FOTOGRAFÍAS}

Varios artistas, como Claudio Linati y más tarde Casimiro Castro, Hesiquio Iriarte y Andrés Camíllo, entre otros, plasmaron en láminas retratos de las costumbres y la vida cotidiana de los mexicanos durante el siglo XIX (Barros y Buenrostro, 2003). Escenas y oficios callejeros ofrecen una amalgama plástica de las zonas de luz y sombra de la hermosa, cautivante y compleja Ciudad de los Palacios, teñida en esos momentos con el sello constructor e ilustrado del emperador y a la vez empobrecida por la escasez de empleos y de circulante.

\section{El espacio macro-lugar macro}

Una buena parte de los mexicanos que vivió durante el siglo XIX conoció sólo el pueblo donde nació. En el centro de las localidades estaban la iglesia, el palacio municipal, la plaza con su tradicional quiosco, unos cuantos comercios y alrededor de estas edificaciones los terrenos con sus casas. La mayoría de los pueblos del centro de México tenía entre 500 y 


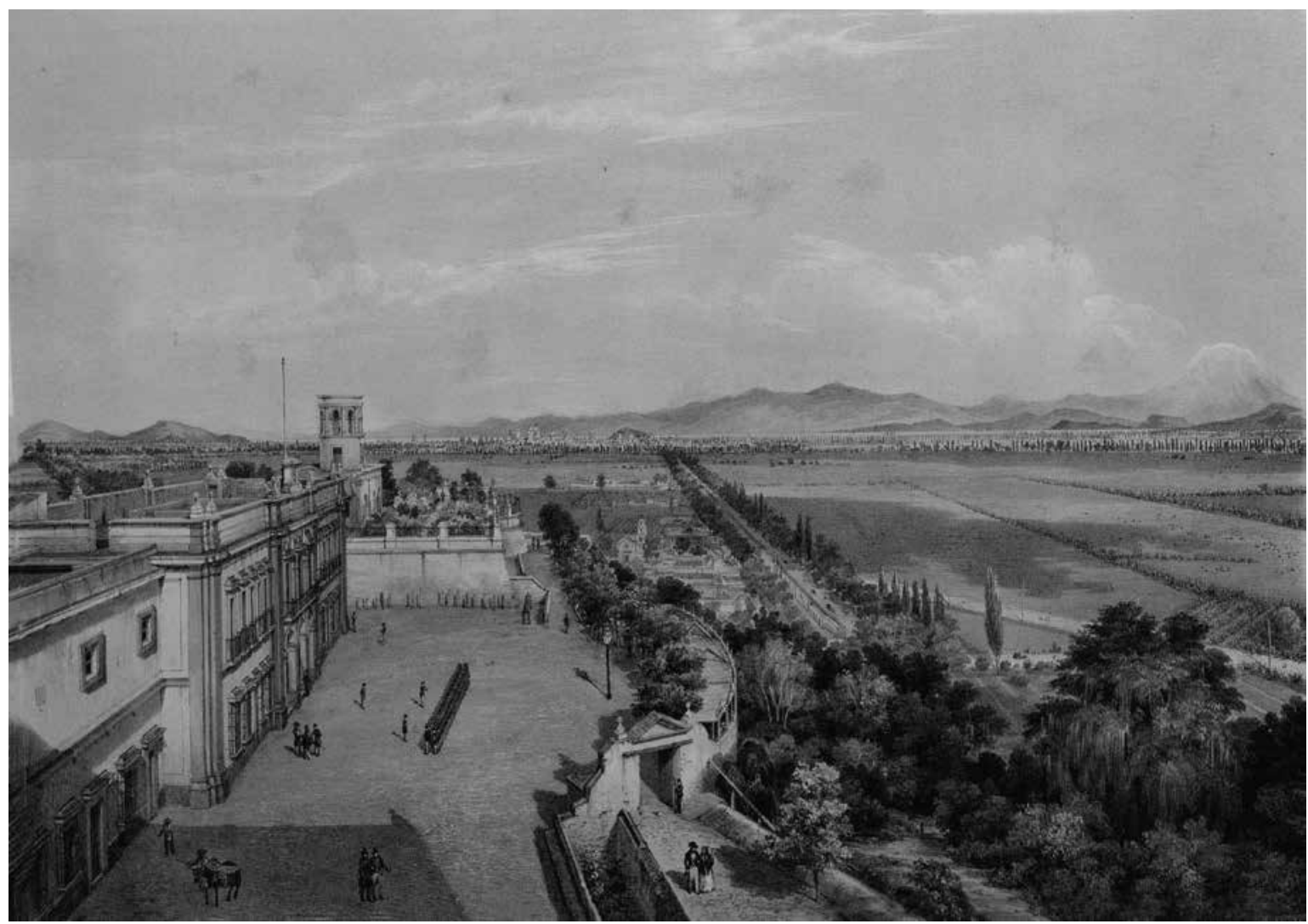

Figura 1. Casimiro Castro, "El Valle de México. Tomado desde las alturas de Chapultepec", 1855-1856.

2000 habitantes, quienes se dedicaban por lo regular a la agricultura de temporal, que proporcionaba escasos recursos para la supervivencia familiar. Naucalpan, donde trabajaba el maestro Neve hacia 1866, era un pueblo típico, con estas características.

El macroespacio, para Neve, constaba de 5 a 20 kilómetros, recorridos en carruaje, a caballo o a pie. En ese tiempo tener caballo era considerado un lujo, de manera que $80 \%$ de los mexicanos caminaba durante horas. Con base en varios mapas y pinturas de la época, documentos históricos del Archivo Histórico Municipal de Naucalpan de Juárez (AHMN) y el Fondo Segundo Imperio del Archivo General de la Nación (AGN), así como en algunos textos literarios, he podido imaginar el trayecto de Maximiliano de Chapultepec a San Bartolo - Naucalpan de Juárez-, cabecera de ayuntamiento. Neve esperaba la visita del emperador a la escuela donde trabajaba, en respuesta a su invitación. Sin duda, este día fue uno de los más importantes en su vida. Él también hizo este trayecto de 10 kilómetros varias veces, pues era común entre los profesores más emprendedores y combativos cambiar de trabajo con frecuencia o bien regresar a éste, como en el caso de Neve, con la intención de aumentar el salario y mejorar las condiciones laborales, sin percatarse acaso de lo estéril de dicha práctica.

El Imperio fue una época de gran inestabilidad y falta de trabajo, vivir de fiado fue más costumbre que excepción. La escasez de dinero provocó que las casas de empeño se multiplicaran a 98 establecimientos en los barrios de la ciudad de México (Directorio 


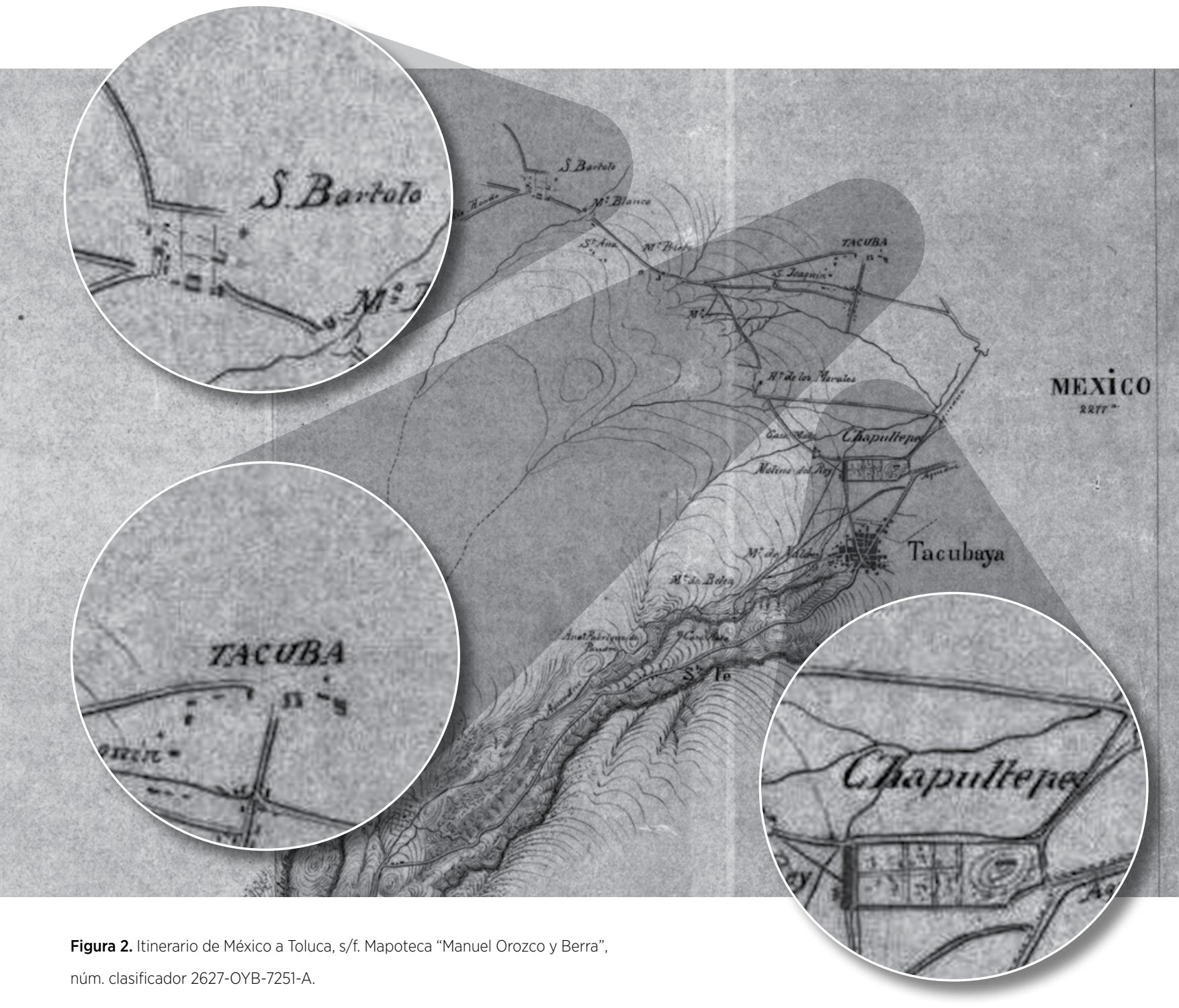

telefónico de la Ciudad de México. Año de 1891, 1979 : 257). La gente entregaba prendas tan humildes como una enagua, una olla de peltre, una sábana, una estampa de Jesús María, objetos que valían de medio real a dos reales. Ocho reales equivalían a un peso. El Monte de Piedad sólo aceptaba prendas con un valor superior a dos pesos (François, 2006: 95).

Un factor importante para que un maestro permaneciera en determinado sitio era la recepción y calidez que le mostraba la comunidad. En el caso de Clemente Antonio Neve, su afán de protagonismo,

que rayaba en la pedantería y causaba constantes disputas, provocaba, al poco tiempo de haber llegado a un pueblo, hostigamiento y rechazo en la vecindad. Varias veces, padres de familia y autoridades municipales lo presionaron para que renunciara, no sin antes reconocer su talento para la docencia.

Como se sabe, a Su Majestad le gustaba visitar los pueblos y convivir con su gente. Buscaba en particular las ocasiones para ayudar y motivar a los habitantes, sobre todo pobres e indígenas. Cuando Clemente Antonio Neve lo invitó a visitar su 


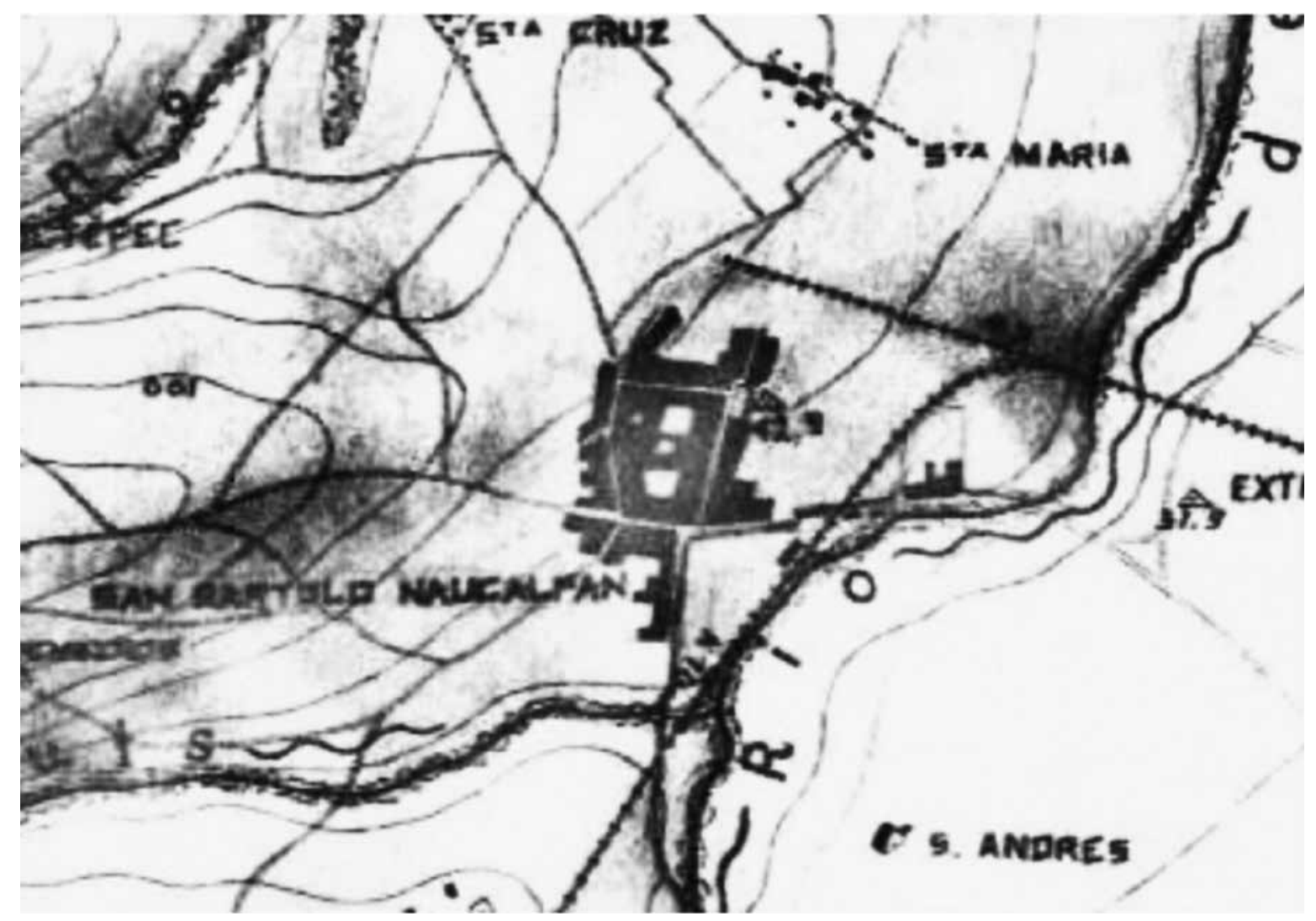

Figura 3. Detalle del mapa de San Bartolo Naucalpan. Archivo Municipal de Naucalpan.

escuela el 1 de junio de 1866, aceptó gustoso. El emperador acostumbraba realizar estas visitas durante los meses de junio y diciembre, cuando se celebraban los exámenes finales.

En aquellos años la educación dependía de los municipios, y como éstos por lo general no tenían recursos, los planteles estaban en muy malas condiciones. El salón escolar se ubicaba casi siempre dentro del palacio municipal o en un terreno regalado por algún vecino. Los habitantes edificaban un saloncito rústico con adobe, techo de paja o teja y piso de tierra. El ayuntamiento se encargaba de pagarle al maestro. Su sueldo provenía de las cuotas del impuesto de instrucción pública que pagaban los habitantes y éstas dependían de una buena o mala cosecha, por lo que la recaudación casi siempre resultaba insuficiente. Las cosechas también determinaban la asistencia de los niños a la escuela. Con frecuencia faltaban casi toda la temporada debido a que ayudaban a sus padres en esas faenas. En esta época, primero se enseñaba a leer y luego a escribir, de manera que los educandos aprendían medianamente lo primero y casi nunca lo segundo. Fue hasta el porfiriato cuando estas habilidades se impartieron de modo simultáneo.

José Blasio, secretario particular de Maximiliano, viajaba siempre con él. Entre sus funciones, anotaba las necesidades que presentaban las comunidades. Además de una libreta, Blasio cargaba una maleta llena de condecoraciones: diplomas, medallas de plata, oro y bronce, y monedas de oro y plata. La maleta siempre estaba a la mano, pues cuando el 


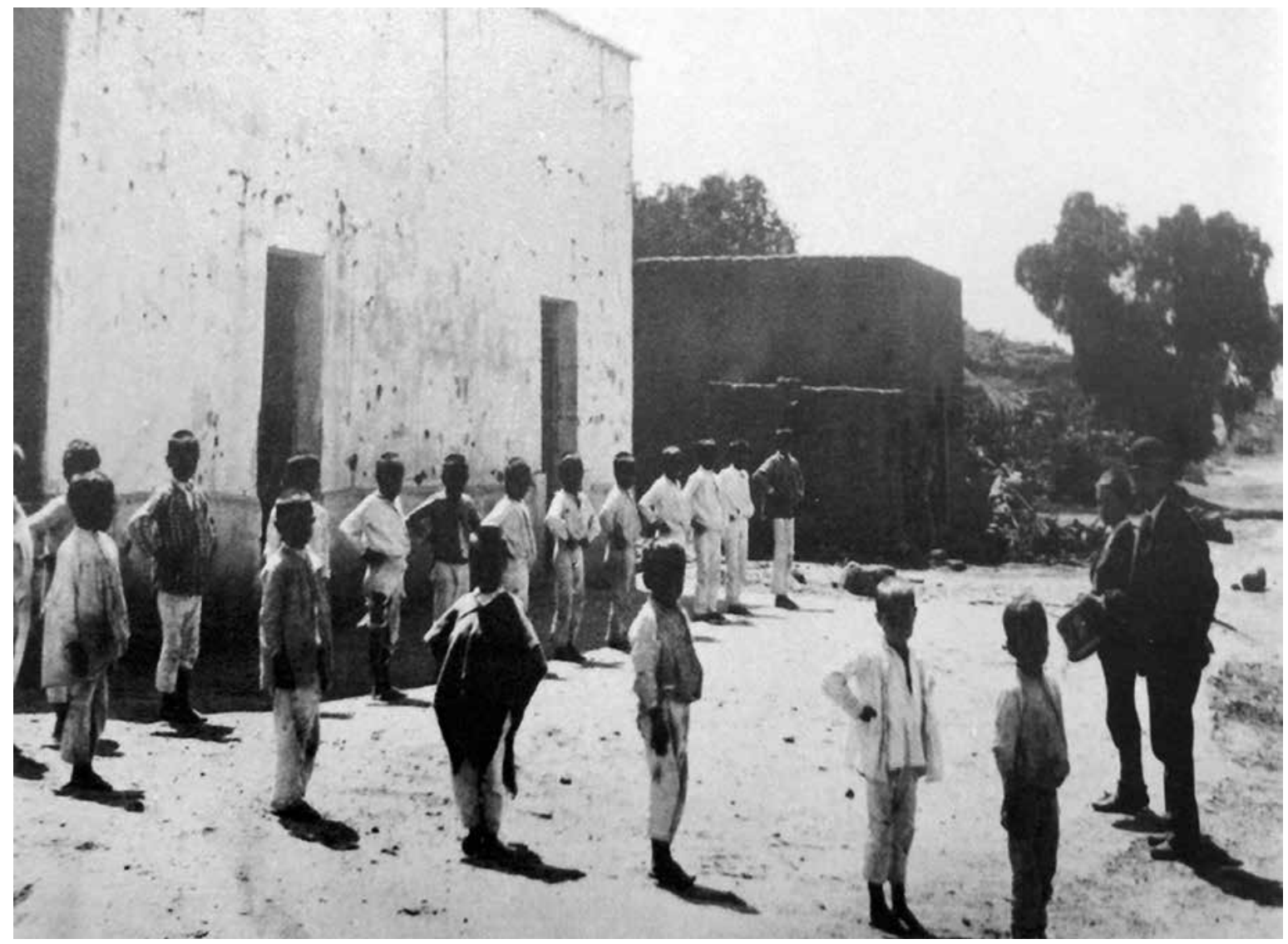

Figura 4. Escuela rural, fototeca del Archivo General de la Nación, Fondo Archivo Histórico de la Secretaría de Educació Pública, caja 1, s/n.

soberano recorría pueblos, haciendas y ciudades dejaba alguna condecoración "como huella benéfica de su paso" (Blasio, 1966: 32).

El día señalado para la célebre visita fue una jornada importante, tanto como el festejo del 15 de septiembre. Autoridades municipales, padres de familia, maestro y chiquillos se pusieron sus mejores galas y todos se afanaron para que el "acto público" tuviera el máximo "lucimiento" posible. La fecha cumbre de la educación se consolidaba en este evento particularmente emotivo en la vida quieta de los pueblos. Neve tenía experiencia de varios años en preparar a los alumnos y decía que se ponían tan nerviosos que corrían el peligro de perder la vida.
El 1 de junio de 1866, el emperador Maximiliano recorrería el camino de travesía ${ }^{6}$ del Castillo de Chapultepec hasta San Bartolo Naucalpan. En la figura 1 se observa una pintura elaborada desde el castillo, a la derecha se aprecia el recién inaugurado Paseo de la Emperatriz — Paseo de la Reforma-, como lo bautizó Maximiliano. Con el objetivo de comunicar por vía directa su residencia, el castillo, con

Los caminos de travesía enlazaban la capital de un estado con otra; los vecinales, la capital de un estado con las cabeceras de distrito; los generales, la capital de la república con las capitales de los estados. En esa época sólo había dos tramos de ferrocarril: de la ciudad de México a la villa de Guadalupe y el de Veracruz a Tejería (De León, 1962: 31, 52). 
su lugar de trabajo, el Palacio Imperial, ordenó trazar esta calzada bordeada por caminos peatonales, custodiados por líneas paralelas arboladas.

A ambos lados de la calzada se advierten algunas construcciones, que son haciendas con sus sembradíos de maíz, trigo o cebada, actuales colonias Cuauhtémoc, Juárez y Roma. Perpendicular corre otra calzada, también bordeada por árboles, que desembocaba en el camino que se dirigía hacia el oeste, se llamaba de la Verónica y hoy es Circuito Interior. Fue la que tomó el emperador para ir a Naucalpan. Al fondo, sobresalen las torres de la catedral de la ciudad de México y en la lejanía se percibe el lago de Texcoco. En el extremo derecho se encuentra el volcán Iztaccíhuatl. El cielo y las nubes algodonosas completan el panorama y ayudan a recrear este gran espacio en el cual vivió Neve, que imaginaron y recrearon aquellos artistas del siglo XIX en su afán por transmitir, como aspiración suprema del arte, no sólo las formas y el color sino el sabor y el olor.

El carruaje del emperador tomó el Camino Real de Tacuba y al cabo de unas horas alcanzó un costado del antiguo convento de San Jacinto y las haciendas de San Jacinto y Santo Tomás, donde se había asentado en 1853 la Escuela de Agricultura, durante el último régimen de Santa Anna. Por ahí ya era campo abierto, lleno de milpas recién sembradas, matorrales y unas cuantas chozas (véase la figura 2$){ }^{7}$

La vista se perdía en el horizonte, en un paisaje agreste y sosegado. La luz era de una intensidad tal que los árboles reflejaban sus siluetas verdes y azules a los costados del camino. El olor balsámico de la lluvia recién caída penetraba por las portezuelas del carruaje y alimentaba el espíritu romántico del emperador, quien, en palabras de Blasio, tenía por la naturaleza la pasión de Rousseau: “amaba las plantas, sus colores, sus formas variadas, sus perfumes, las cultivaba como hombre de gusto y artista y las describía como poeta" (Blasio, 1966: 234).
En Popotla lograron divisar, entre unos cuantos olivos, el famoso ahuehuete, el Árbol de la Noche Triste. Después de atravesar una calzada polvosa, bordeada por magueyes y sauces, llegaron a Tacuba. En esos momentos, las lluvias habían causado estragos en los caminos, incluso en ese principal de Tacuba, y eso afectaba de forma alarmante todos los aspectos de la vida cotidiana de la población, entre ellos la educación. No todos los pueblos, haciendas y rancherías tenían escuelas. Para abreviar distancias, maestros y alumnos caminaban durante horas por veredas y atajos, que también se tornaban intransitables por lo crecido de los ríos. Neve lamentó este hecho innumerables ocasiones, pero esa pasión casi enfermiza por el cumplimiento de su deber docente lo cegaba ante los problemas de sus alumnos y no perdonaba las faltas, así hubieran caído aguaceros.

Después de tres horas, Maximiliano arribó a Naucalpan, donde lo esperaban Neve y las autoridades municipales (véase la figura 3). En la figura 4 se aprecia una escuela rural como pudo haber sido la de Neve en Naucalpan: el maestro viste traje negro y bombín, como se usaba en los exámenes públicos, y los alumnos indígenas usan calzón y camisa de manta. Se observan algunas prendas rotas y sucias, y que casi todos los niños están descalzos. ${ }^{8}$

\section{Escuela rural}

Como muchos maestros, Neve se enfrentaba a lo que alguna vez un profesor de esa época dijo: "La escuela es para el niño indio un planeta inhabitable". Los alumnos no hablaban español - Neve hablaba náhuatl y muchos otros profesores hablaban lenguas

7 "Itinerario de México a Toluca", s. f., disponible en línea: <http://w2.siap.sagarpa.gob.mx/mapoteca/mapas/2627OYB-7251-A.jpg>.

$8 \quad$ AGN, Documentos gráficos..., pp. 126. 
nativas-, llegaban al plantel sin haber probado bocado y sus condiciones de vida eran miserables. Éste era el escenario escolar cotidiano al que se enfrentaba el profesor. Ese memorable día, Maximiliano le regaló a Neve 10 medallas para sus alumnos, y además, como acostumbraba, 100 pesos. El profesor hizo castillos en el aire y soñó con que ahora sí su plantel tendría lo necesario: textos, cuadernos, lápices, bancas. Sin embargo, las autoridades municipales hicieron perdedizo el dinero y por tal motivo Neve casi perdió sus casillas. Le escribió a Maximiliano condenando "los abusos de los funcionarios y [...] la mala fe de los hombres que no se ha de acabar en México", pero no volvió a ver los 100 pesos. ${ }^{9}$

\section{El espacio medio-lugar medio}

La Ciudad de los Palacios, como la bautizó Charles Joseph Latrobe (1836), mantenía casi el mismo tamaño desde finales del siglo XVIII y guardaba desde entonces la misma división en cuarteles mayores y menores. La traza de la ciudad colonial había respetado las calzadas de Tenochtitlan-Tlaltelolco, que unían la isla donde está el Templo Mayor hacia los cuatro puntos cardinales. En 1830 se habían reacomodado calles, plazas y plazuelas y se atribuyó un valor catastral a los terrenos: los más caros se ubicaban cerca de la catedral y se orientaban hacia el oeste. La zona noreste, donde radicó Neve la mayor parte del tiempo - los mexicanos solían cambiar de domicilio muchas veces porque no podían pagar la renta-, no era de las privilegiadas, pues justo hacia el lado contrario, el oeste, donde se ubicaba la Alameda, se decía que corría el aire más puro, que venía de la zona de Chapultepec, sombreada por los hermosos ahuehuetes llevados por Nezahualcóyotl, el rey poeta de Texcoco (véase la figura 5). ${ }^{10}$

La ciudad tenía 200000 habitantes y medía, de Norte a Sur y de Este a Oeste, aproximadamente 5 kilómetros. La hermosura que mostraba la urbe era mermada por el aire pestilente y su estado contaminante, pues la gente pobre solía orinar y defecar en la vía pública. ${ }^{11}$ Desde la época de la Colonia existían carros jalados por mulas que pasaban día y noche vaciando las letrinas de las viviendas. Sin embargo, esto no solucionaba la fétida atmósfera (Lafragua y Orozco, 1998: 123).

El espacio-lugar medio está representado por el tránsito de Clemente Antonio Neve por la ciudad de México: de sus casas a las escuelas, al ayuntamiento —donde acudía a buscar empleo o a lamentarse de las condiciones laborales-, al correo - la gente ilustrada escribía entre 10 y 15 cartas diarias-, al mercado, entre otros lugares insertos en la rutina del profesor. Como muchos maestros que vivieron en la ciudad de México durante la segunda mitad del siglo XIX, Clemente Antonio Neve habitó en varias "casas". Más bien en una, dos, tres o cuatro "piezas" dentro de las típicas viviendas mexicanas, en las que habitaban de 100 a 150 personas que compartían lavaderos y letrinas. Muy pocos citadinos, quizá 10 o 15\%, poseían la casa donde vivían.

Justo cuando Clemente Antonio Neve llegó a la ciudad de México en 1861, Juárez había declarado la desamortización de los bienes de la Iglesia, de modo que le tocó ver la demolición de los 19 conventos de hombres y 21 de mujeres, para ser atravesados por nuevas calles, como Independencia, Gante, Colón, Balderas y Humboldt. Parecía que la urbe hubiera sido arrasada por un terremoto (Tovar, 1990: 19; véase la figura 6).

9 Clemente Antonio Neve, "Carta del 19 de julio de 1866", AGN, Instrucción Pública y Bellas Artes, 2a. parte, caja 12, exp. 1, ff. 1-5.

10 "Panorama of the City of Mexico", 1858, disponible en línea: <http://w2.siap.sagarpa.gob.mx/mapoteca/mapas/3284OYB-725-A.jpg>.

11 Durante el siglo XIX se pensaba todavía que las enfermedades provenían de los gases emanados de los miasmas. En 1898, el paradigma miasmático de la enfermedad cambió al paradigma microbiano. 


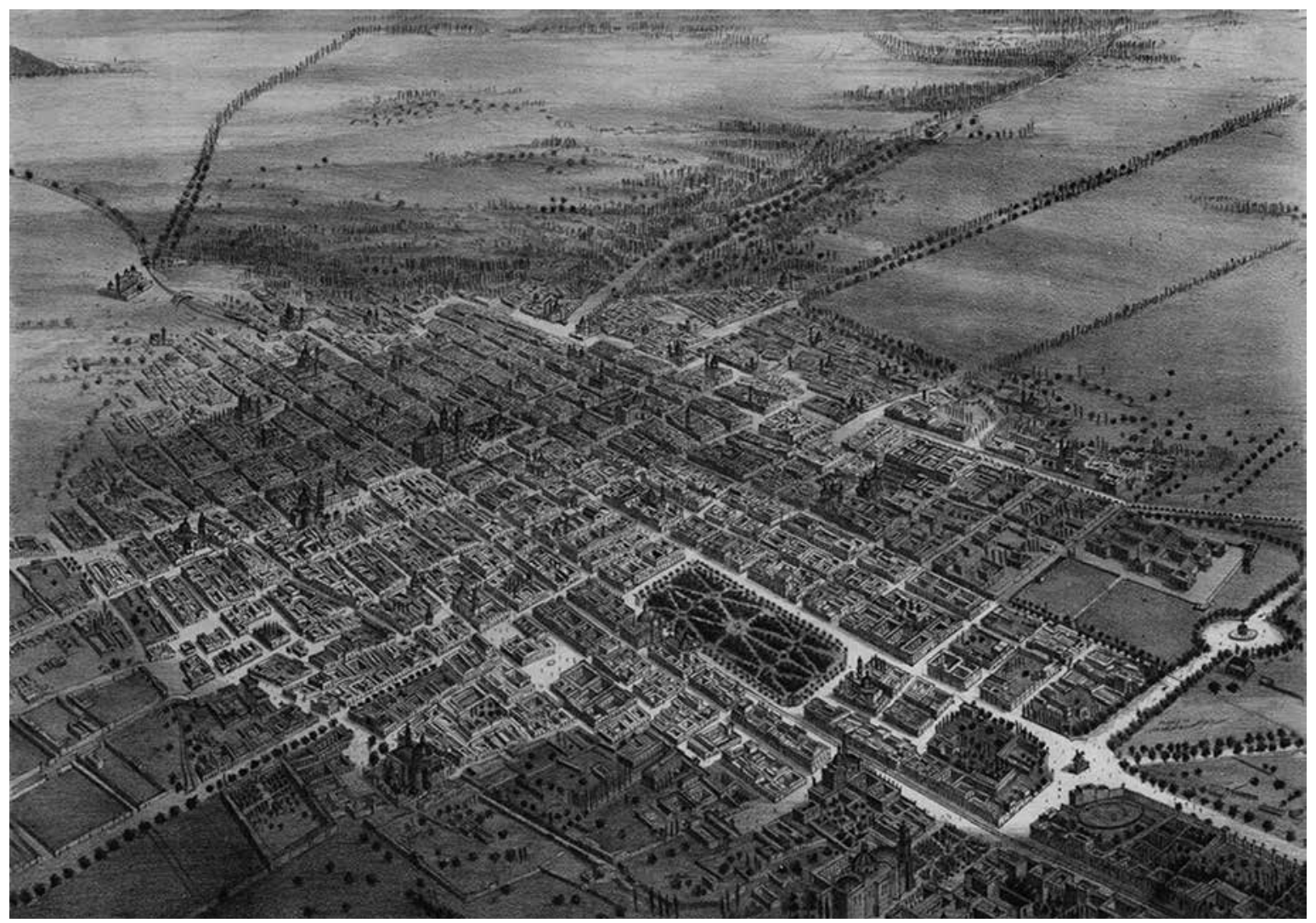

Figura 5. Casimiro Castro, "La ciudad de México tomada en globo", 1855-1856.

Surgían entonces los indicios del México moderno. La ciudad adquiría poco a poco los aires renovados del progreso. Ya no se verían por las "calles de Dios" a los frailes con hábitos, sayales o cerquillos. Por otra parte, el constante repicar de las campanas de las iglesias había disminuido para dar lugar, lento pero seguro, a los sonidos con aires de modernidad, ruidos urbanos provenientes de la algarabía de los transeúntes que atravesaban las nuevas vías.

Como se puede observar en la figura $7 \mathrm{a},{ }^{12} \mathrm{Ne}-$ ve habitó la mayor parte del tiempo en la zona norte y este de la ciudad. En 1864, encontró alojamiento en Puente del Carmen número 13, domicilio ocupado hoy por el edificio moderno del Monte de Piedad, a unas siete cuadras al noreste de la catedral y al sur de San Antonio Tepito. Era uno de los barrios más pobres, contaminados y pestilentes, donde vivían artesanos, trabajadores y sirvientes. La calle conservaba el nombre con el cual fue bautizada en la época colonial. Esta vía era "calle de agua", es decir, un canal antiguo sobre el cual se había construido un puente (Lafragua y Orozco, 1998: 77).

Se encontraba a un costado del convento del Carmen, entonces en ruinas porque estaba siendo dividido en lotes, a causa de la desamortización, para ser vendidos. El convento daba nombre no sólo a la arteria, también al barrio, considerado en los suburbios

12

"Plano general de la ciudad de México, 1861", disponible en línea: <http://w2.siap.sagarpa.gob.mx/mapoteca/mapas/ 920-OYB-725-A.jpg>. 


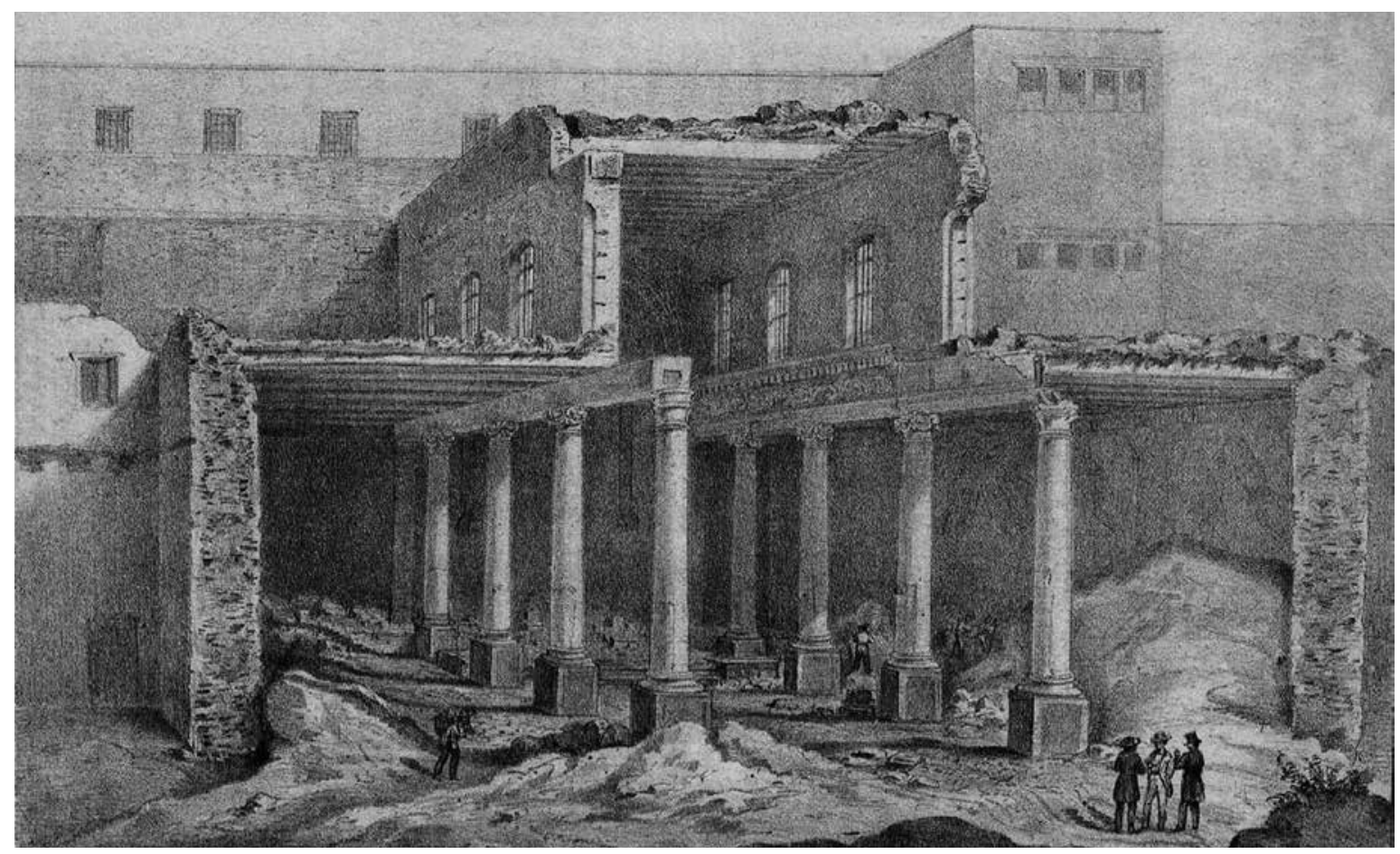

Figura 6. Litografía de Iriarte y Compañía, "Ruinas de la capilla de los servitas”, 1861.

de la ciudad. Aunque la ley juarista prohibió el derrumbamiento de las iglesias y las obras de arte, la incontrolable piqueta destruyó buena parte del patrimonio artístico de la ciudad, como la iglesia del Carmen. Todavía había canales o acalotes, cuyas aguas fluían hasta el lago de Texcoco, por los cuales transitaban trajineras, canoas e incluso barcos pequeños, como afirma José María Marroquí, que transportaban todo tipo de víveres y flores. Al puerto de Iztacalco llegaban las semillas y los granos de las haciendas situadas al margen del lago de Texcoco (Ciudadanos en Red, 2010; véase la figura 8), frutos de Tierra Caliente que conducían los arrieros hasta Chalco, carbón, leña y madera que se labraba en las montañas y otros productos de consumo indispensable para los habitantes (Payno, 2001: 148). Pese a la comodidad de este medio de transporte y la belleza que brotaba del colorido de las mercancías, las acequias estaban colmadas de basura y eran fuente de suciedad e infección.
En 1865, Neve trabajaba en la escuela de la Corte número 44, en San Juan de Aragón, a unos 5 kilómetros de su casa en Chavarría - hoy, calle Justo Sierra - número 2 (véase la figura 7b). ${ }^{13}$ Caminaba entre 45 y 60 minutos prácticamente a campo abierto, por los potreros de la hacienda de Aragón, en los que vivían familias dispersas en condición miserable (Lira, 1983: 274). Tal vez el bajo sueldo de 20 pesos al mes le hiciera pensar que abrir su propia escuela era una buena idea. La gran cantidad de planteles privados que proliferó durante el Imperio representaba un negocio que podía ser lucrativo. La mayoría de los colegios particulares anunciaba que cobraría "precios módicos". Ello se debía a que

"Plano general de la ciudad de México, 1861", disponible en línea:<http://w2.siap.sagarpa.gob.mx/mapoteca/mapas/ 920-OYB-725-A.jpg>. 


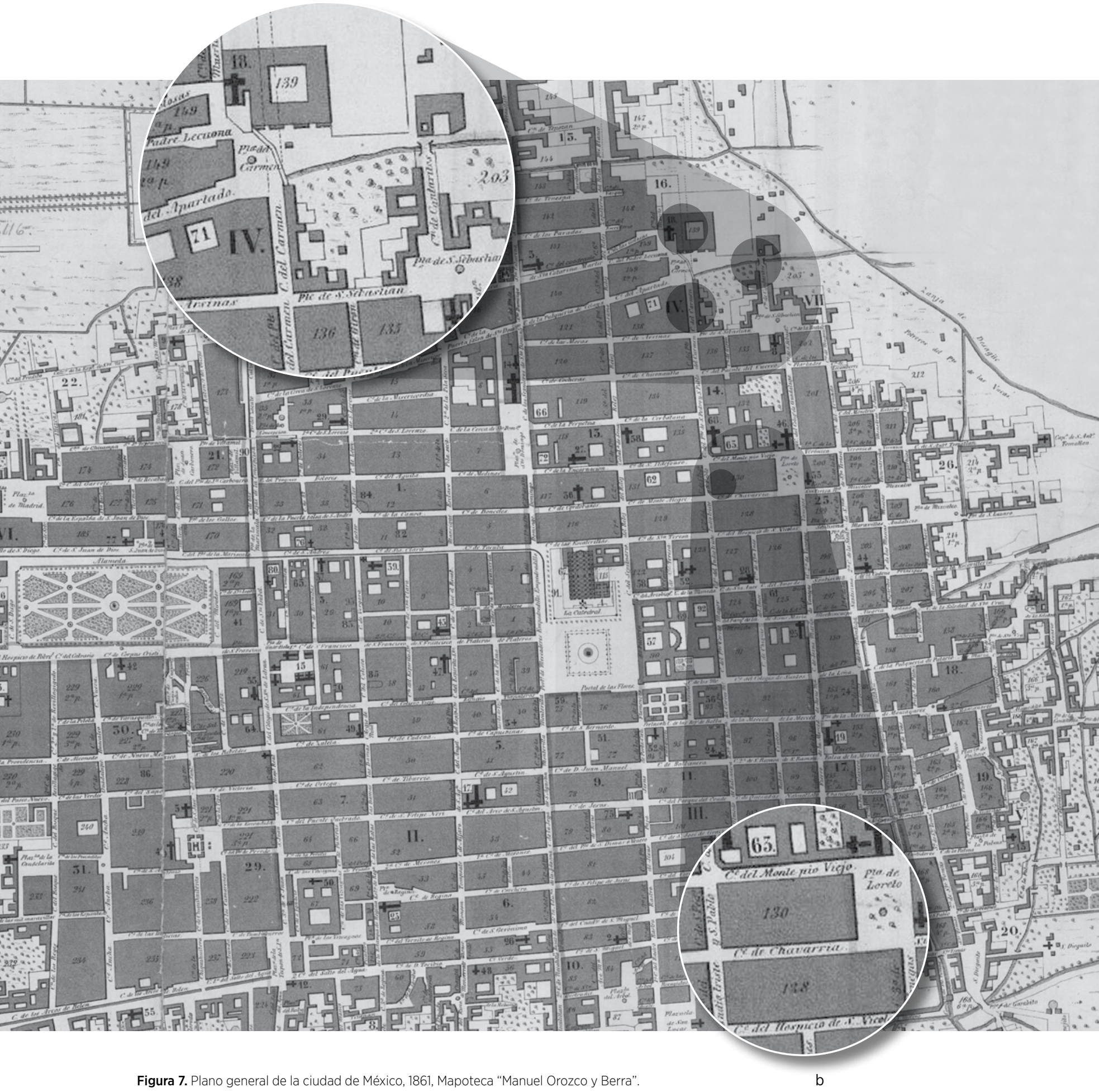

(a) Calle del Carmen, Convento del Carmen y puente de calle de agua.

(b) Calle de Chavarría. 


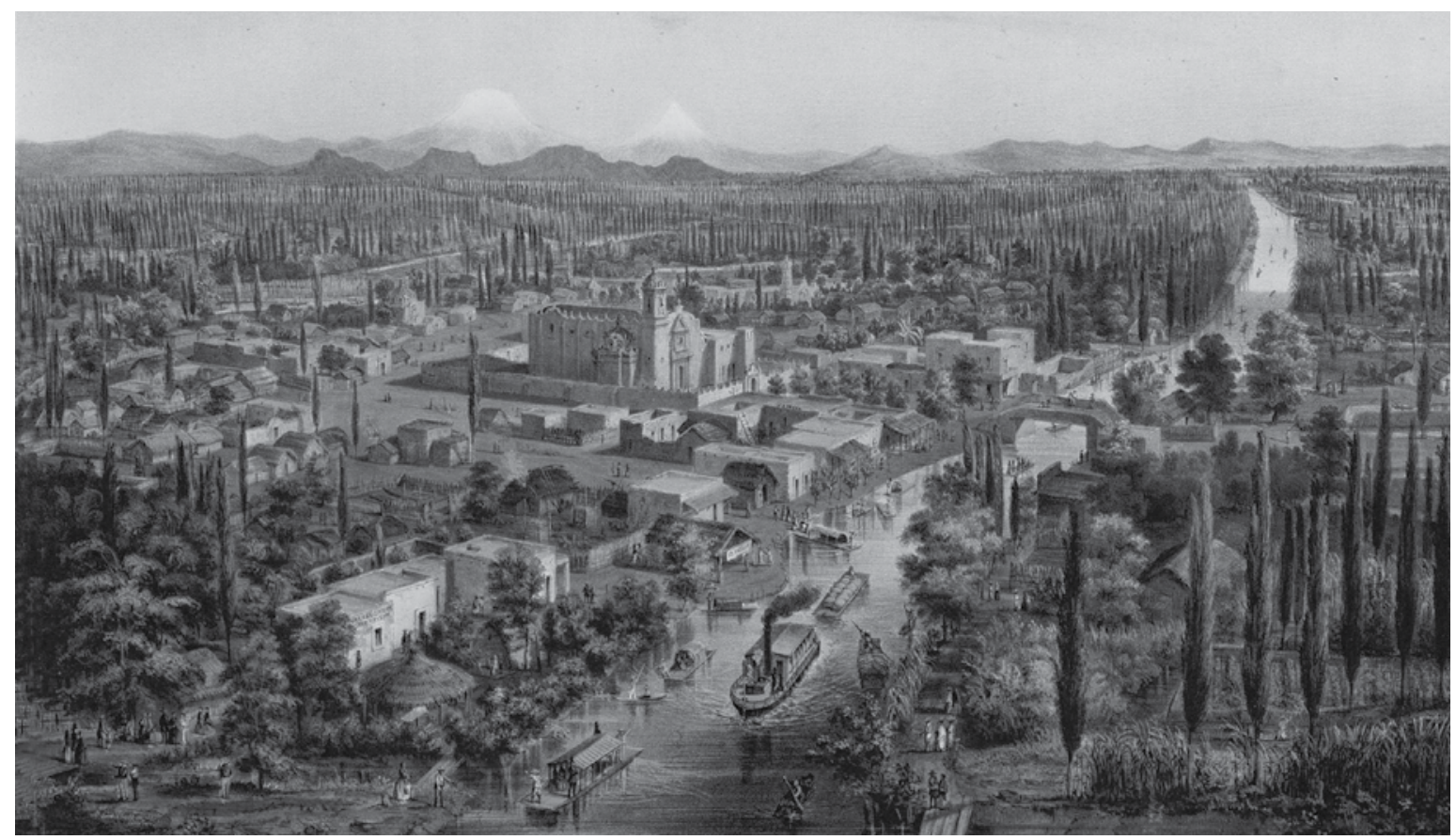

Figura 8. Casimiro Castro, “El pueblo de Ixtacalco", 1855-1856.

tenían que colmar la demanda no sólo de las clases pudientes sino también de la naciente clase media formada por profesionistas, comerciantes y maestros. En la época imperial la gente "decente" solía mandar a sus hijos a colegios privados, muchos de ellos afrancesados, para que no se mezclaran con los "peladitos" de las escuelas municipales, aunque éstas podían ser tan buenas como aquéllas.

La ley imperial exigía la enseñanza de ciertas materias básicas. Las escuelas privadas podían impartir otras, si sus directores así lo deseaban. Como en épocas anteriores, y también posteriores, había una total libertad en la elección de las asignaturas, siempre bajo la férula del ayuntamiento, que inspeccionaba periódicamente el funcionamiento de los planteles, públicos y privados. ${ }^{14}$

Además de las asignaturas comunes, el elenco de materias que propuso Neve ofrecía un curso de moral en lugar del de "principios de religión" que exigía el Imperio, medida que muestra su pensamiento moderno. Esto difería de la norma, pues las escuelas privadas solían ser religiosas, no laicas. La de Neve pudo haber llamado la atención, pero no necesariamente para aumentar las inscripciones. En esa época, las familias, la mayoría católicas, preferían planteles que ofrecieran una formación religiosa.

Como resultaría obvio, en la práctica le fue imposible atender dos escuelas a la vez, sobre todo por la distancia entre la suya y la de San Juan de Aragón. Una vez más, intentó gestionar ante las autoridades que un ayudante pudiese auxiliarlo en su ambiciosa empresa. Proponía alternar la dirección, y por

Los periódicos se encargaban de delatar la falta de inspección. Por ejemplo, el 17 de marzo de 1865, Los Espejuelos del Diablo recomendaba la vigilancia a cierta escuela "amiga" cuya directora abandonaba con frecuencia a sus alumnas y éstas "se volvían locas". Véase también el 13 de marzo de 1865. 


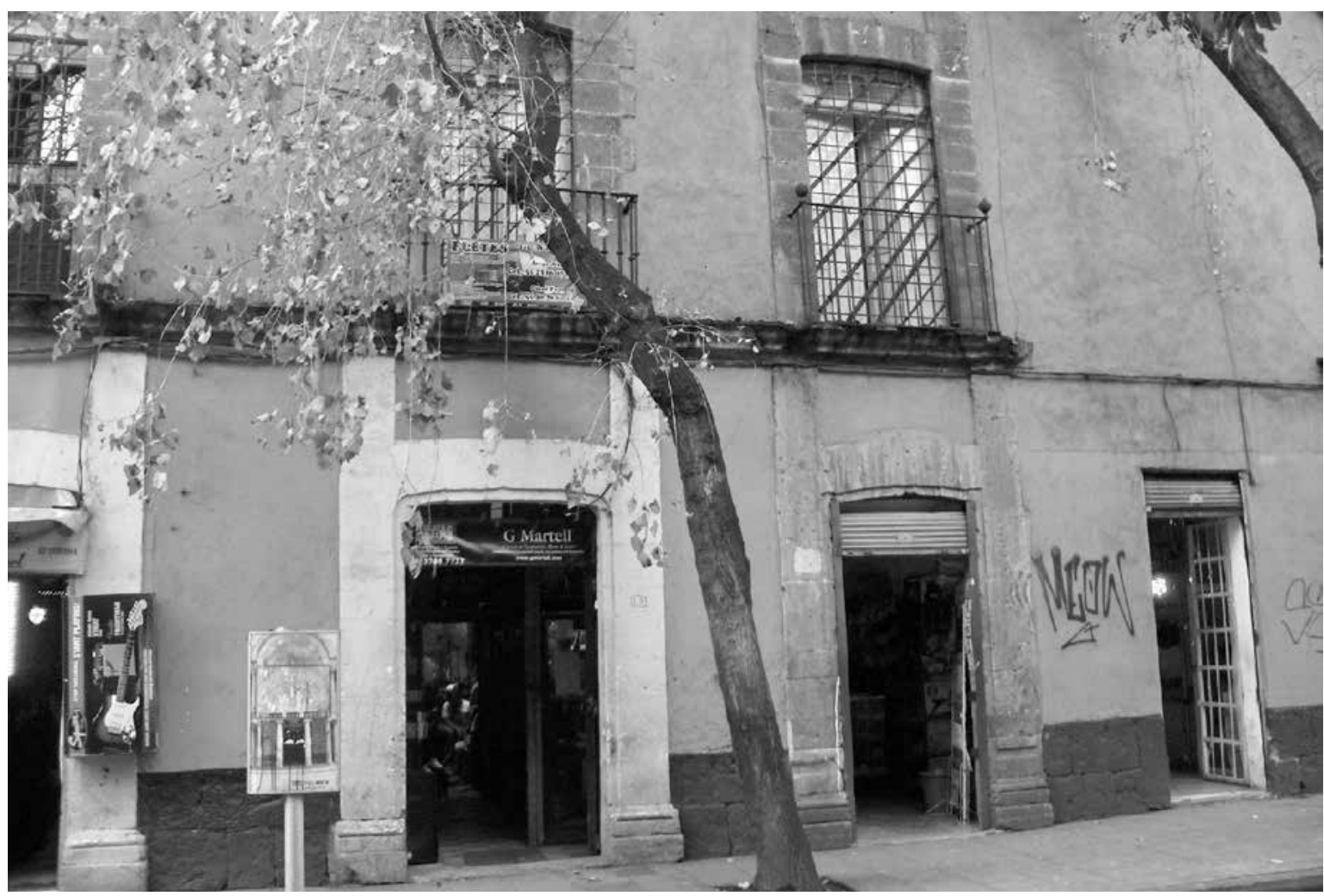

Figura 9. Casa-vivienda y Liceo Patriótico Jesús Nazareno. Foto: Mílada Bazant.

lo tanto, la enseñanza en ambos planteles, tres días cada uno. ${ }^{15}$ Según se desprende de los documentos, el ambicioso proyecto de Neve no tuvo el éxito esperado. A los pocos meses se vio forzado a solicitar una plaza, lo que indica que no tuvo éxito en su proyecto particular ni como maestro municipal. Abrumado por tantas derrotas y una supervivencia tan precaria, sorprende su fortaleza para seguir adelante, obtenida quizá de la presión de mantener a una esposa y tres hijos, y sin duda de su pasión por el magisterio.

A finales de 1865 el incansable Neve se había cambiado de domicilio una vez más y había fundado el Liceo Patriótico Jesús Nazareno, llamado así por cierta presunción afrancesada. Su vivienda y la escuela ocupaban un cuarto al lado del otro en el número 15-2 de la primera calle de Mesones.

La fachada de la casa permanece intacta (véase la figura 9), no así el interior, que salvo un barandal fue destruido (véase la figura 10).

En este cuartel menor 1, ubicado a unas ocho cuadras de la catedral, se levantaban casas señoriales y viviendas. Habitaban el mismo espacio 17 comerciantes, ocho sastres, dos carpinteros, un médico, un curador, dos corredores, dos sombrereros y otros artesanos: 43 jefes de familia. ${ }^{16} \mathrm{Si}$ añadimos a las esposas e hijos, el número de habitantes aumenta tres o cuatro veces.

15 16
AHDF, Fondo Ayuntamiento del Distrito Federal, serie Instrucción Pública, vol. 2484, exp. 896.

AHDF, Fondo Ayuntamiento, serie Padrones, vol. 3415, cuartel menor 1, manzana 48, 1865. 


\section{El espacio-lugar en transición: Salón Iturbide, cumpleaños de Maximiliano}

El empeño docente y la personalidad apasionada de Neve a favor de la educación imperial debió impresionar a Su Majestad, pues al cabo de un mes de haberlo visitado en Naucalpan lo condecoró con la máxima distinción de su Imperio: la Orden de la Cruz de Guadalupe. Esta insignia estaba destinada a los ciudadanos que hubieran realizado alguna labor destacada en beneficio de la patria. Se compone de una cruz de cuatro brazos esmaltados, cada uno con tres hojas de colores verde, blanco y rojo (Cuartoscuro, 2012; véase la figura 11). La medalla de la Orden de Guadalupe tenía varios grados: Gran Maestre para Maximiliano, Grandes Cruces, Grandes Oficiales, Grandes Comendadores y Caballeros, que fue la que recibió Neve, quien señaló: "Es una joya que no abandonaré sino en el sepulcro y que quedará muy recomendada a mi descendencia". ${ }^{17}$

Desde la víspera del viernes 6 de julio, día en que el emperador cumplía 34 años, empezaron a llegar grupos de indígenas de varios pueblos del Valle de México con sus respectivas bandas de música ( $\mathrm{La}$ Sociedad, 6 de julio de 1866). El progresista alcalde municipal Ignacio Trigueros se había empeñado, sobre todo en esa época de aguaceros e inundaciones frecuentes, en mantener transitables las calles céntricas de la metrópoli. Ordenó de modo prioritario que se arreglaran las atarjeas (La Sociedad, 6 de julio de 1866). El decreto imperial del 1 de noviembre de 1865 declaró ese día como festivo, como el Jueves Santo, el 15 de Septiembre y el 12 de Diciembre. Las oficinas de gobierno y todo el comercio, salvo "los expendios de primera necesidad" permanecerían cerrados (Directorio telefónico de la Ciudad de México. Año de 1891, 1979: 4).

Desde las cinco de la mañana, el toque de alba anunció jornada de gala con salvas de artillería, cohetes y repiques de todos los templos. El ceremonial de la corte exigía al innumerable séquito

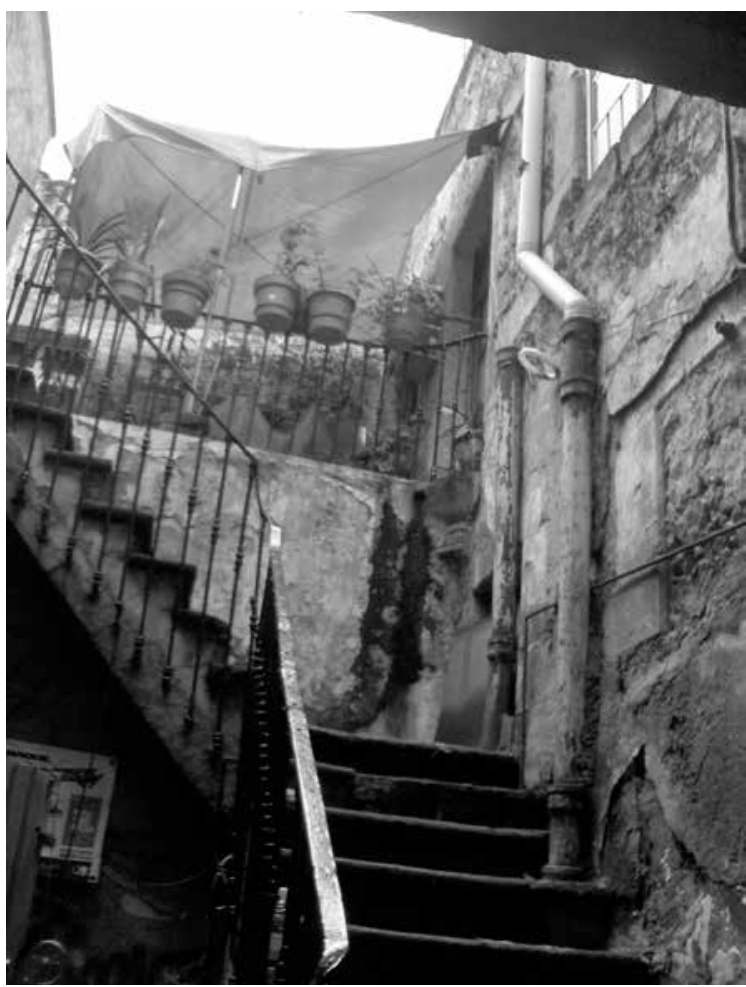

Figura 10. Vestigios de la vivienda donde habitó Clemente Antonio Neve. Foto: Mílada Bazant

que se presentara en el Palacio Imperial en horarios precisos. Se ubicaban en lugares asignados, algunos en formaciones calculadas al milímetro, con uniformes, atuendos, condecoraciones y joyas tan exquisitos que parecían brotadas de cualquier corte europea. México, país republicano, no tenía tradición ni hábitos cortesanos, no tenía pergaminos ni títulos de nobleza; sin embargo, al tiempo de admirar el brillo esplendoroso del Imperio, se desató entre las familias pudientes mexicanas "una fiebre de aristocracia y de nobleza" que buscaba pergaminos, escudos de armas, árboles genealógicos de renombre

17

Carta de Clemente Antonio Neve al emperador Maximiliano, 19 de julio de 1866, AGN, Instrucción Pública y Bellas Artes, 2a. parte, caja 12, exp. 1, f. 1. 


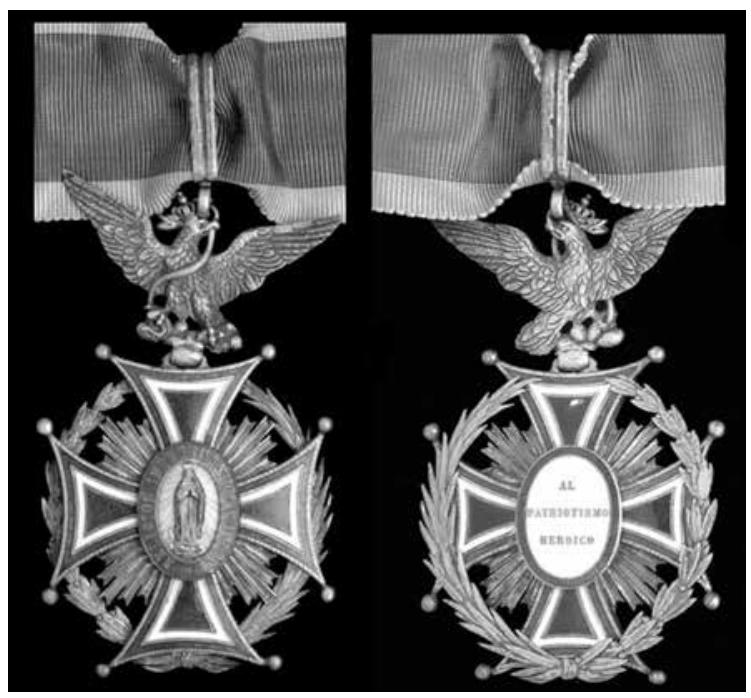

Figura 11. Cruz de Grado, comandante o encomienda de la Orden de Guadalupe. Museo Nacional de Historia.

(Blasio, 1966: 69) y otros tantos títulos que acreditaran que descendían de marqueses, duques y condes y que la sangre azul corría por sus venas. Neve estaba embebido, al igual que muchos mexicanos, con su corte y sus festejos.

A las 11 de la mañana, saludando a la múltiple concurrencia, Sus Majestades recorrieron la Sala de Audiencias, la Galería de Pinturas, la Galería de la Guardia Palatina y la Galería Iturbide, en la cual había más de 600 personas. "Conmovido y lleno de gratitud”, Maximiliano pronunció unas palabras. Luego algunos invitados emitieron discursos "breves, enérgicos y entusiastas”, y regalaron a los emperadores tarjetas y ramos de flores (Diario del Imperio, $6 \mathrm{de}$ julio de 1866).

Posteriormente, salieron al gran patio de $\mathrm{Pa}-$ lacio y a la Plaza de Armas, donde más de 15000 personas los esperaban (La Sociedad, 6 de julio 1866). Ahí se tocó el Himno Nacional y el gran séquito se dirigió a la catedral, donde fueron recibidos por el arzobispo y el cabildo. El recinto estaba a reventar, pues el decreto exigía que "todas las autoridades, empleados civiles y militares y funcionarios públicos de cualquier categoría tenían el deber de asistir a la ceremonia religiosa" (Almanaque de la Corte, 1866; Borja, 2011: 101-115).

Terminada la misa, los emperadores y su séquito se dirigieron de nuevo a Palacio, donde a las dos de la tarde se inauguró el Museo Nacional, ubicado en la anterior Casa de Moneda. Ahí quedarían expuestas muchas piezas prehispánicas, algunas donadas por Maximiliano, quien afirmó que un museo era un lugar donde "se conserva y transmite el pasado mediante el coleccionismo de objetos" y un "espacio para la transmisión de incipientes nociones de patria, nación e identidad común” (Martínez, citado en Acevedo, 2012: 70). Después de esta inauguración, se celebró la premiación en la Galería Iturbide, hoy Salón de Recepciones y Embajadores (véase la figura 12). ${ }^{18}$

A este espacio-lugar lo he llamado "de transición", porque se ubica entre el medio y el micro. Aquel día fue uno de los más importantes en la vida del profesor. Su Majestad, de pie, cerca del trono y con Carlota a su lado, pronunció unas sentidas palabras y en seguida el recién nombrado Gran Canciller de las Órdenes Imperiales, Juan de Dios Peza, “condujo cerca del Emperador a las personas agraciadas con condecoraciones y el emperador se dignó entregárselas a cada uno sin distinción de clase o de categoría cuidando el Canciller que retrocedieran sin dar la espalda a SSMM desde el más alto personaje hasta el más humilde artesano” (Borja, 2011: 103-104).

La única medalla de Gran Oficial se otorgó a José María Lacunza, ministro de Hacienda. Siete personas recibieron el grado de Comendadores, 27 el de Oficiales y 43 el de Caballeros. Entre éstos, además de Clemente Antonio Neve, estaba Miguel Parra, profesor de fisiología y anatomía, y doctor de la Escuela de Agricultura (Maillefert, 1992: 280),

La Galería Iturbide es el recinto donde Clemente Antonio Neve recibió la medalla de la Orden de Guadalupe. 


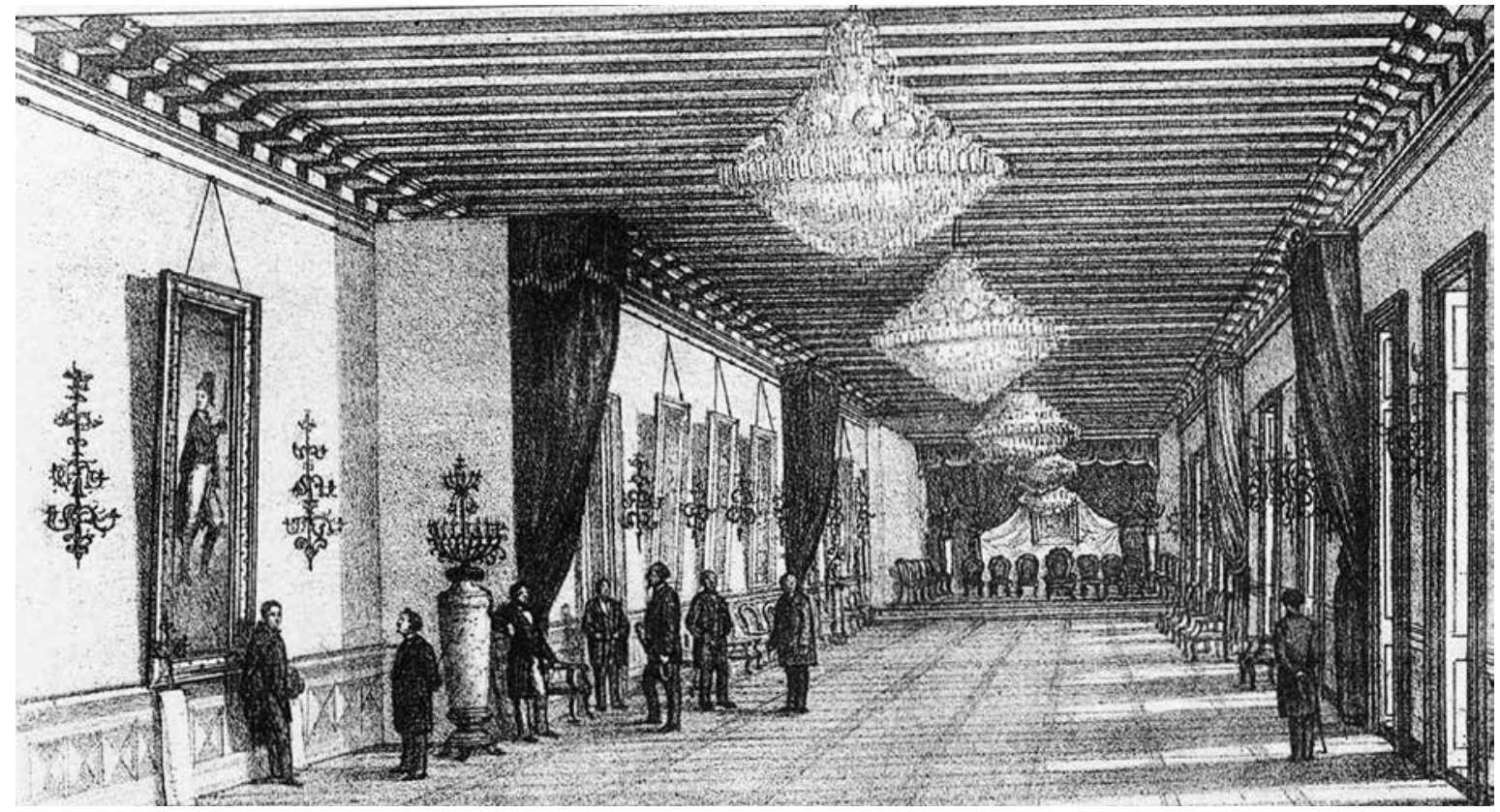

Figura 12. Manuel Rivera Cambas, "Salón de ceremonias ó de Embajadores, en el Palacio Nacional. Allí son recibidos por el Presidente de la República los Ministros extranjeros".

y Eduardo Liceaga, conocido médico. ${ }^{19}$ En los tres últimos grados había gente del interior del país. A partir de entonces, el maestro Clemente Antonio Neve firmaría sus oficios con su nombre y la leyenda "Caballero de la Orden de Guadalupe" (véase la figura 13). ${ }^{20}$ Pensó que su suerte cambiaría y que por fin tendría un trabajo de acuerdo con sus méritos.

\section{El espacio micro-lugar micro}

El espacio íntimo de los seres humanos es su hogar, el punto focal de su estructura cósmica (Bachelard, 1993: 144, 149). Bachelard lo llama "nido", como el refugio de los pájaros, lugar de seguridad y bienestar (Bachelard, 1993: 125). En el siglo XIX, como en la actualidad, los espacios íntimos estaban relacionados con los recursos económicos de las familias. La gente pudiente vivía en una casa sola, mientras que la mayoría de los habitantes de la ciudad, de condición precaria, entre ellos profesionistas, maestros y comerciantes, rentaba uno, dos o tres cuartos dentro de las llamadas viviendas porque eran más baratos.

En este tipo de alojamiento era difícil tener privacidad. Padres e hijos dormían en un cuarto, otro hacía las veces de sala-comedor e incluso de baño, pues en ocasiones se acomodaba una tina de zinc o de madera, se calentaba agua y los miembros de la familia se bañaban por turnos los sábados, cada mes, cada dos meses o cuando buenamente se podía. La sencilla cocina estaba por lo general en la zotehuela, aunque podía haber un anafre encendido con carbón o leña en el interior, en la misma estancia-dormitorio. Los escasos y modestos muebles y

Diario del Imperio, 6 de julio de 1866. La Gran Cruz estaba limitada a 30 miembros, la Gran Oficial a 100 miembros, Comandante a 200 miembros y Caballero a 500 miembros (Borja, 2011).

20 AHDF, Fondo Ayuntamiento del Distrito Federal, serie Instrucción Pública, vol. 2482, exp. 689, f. 3. 


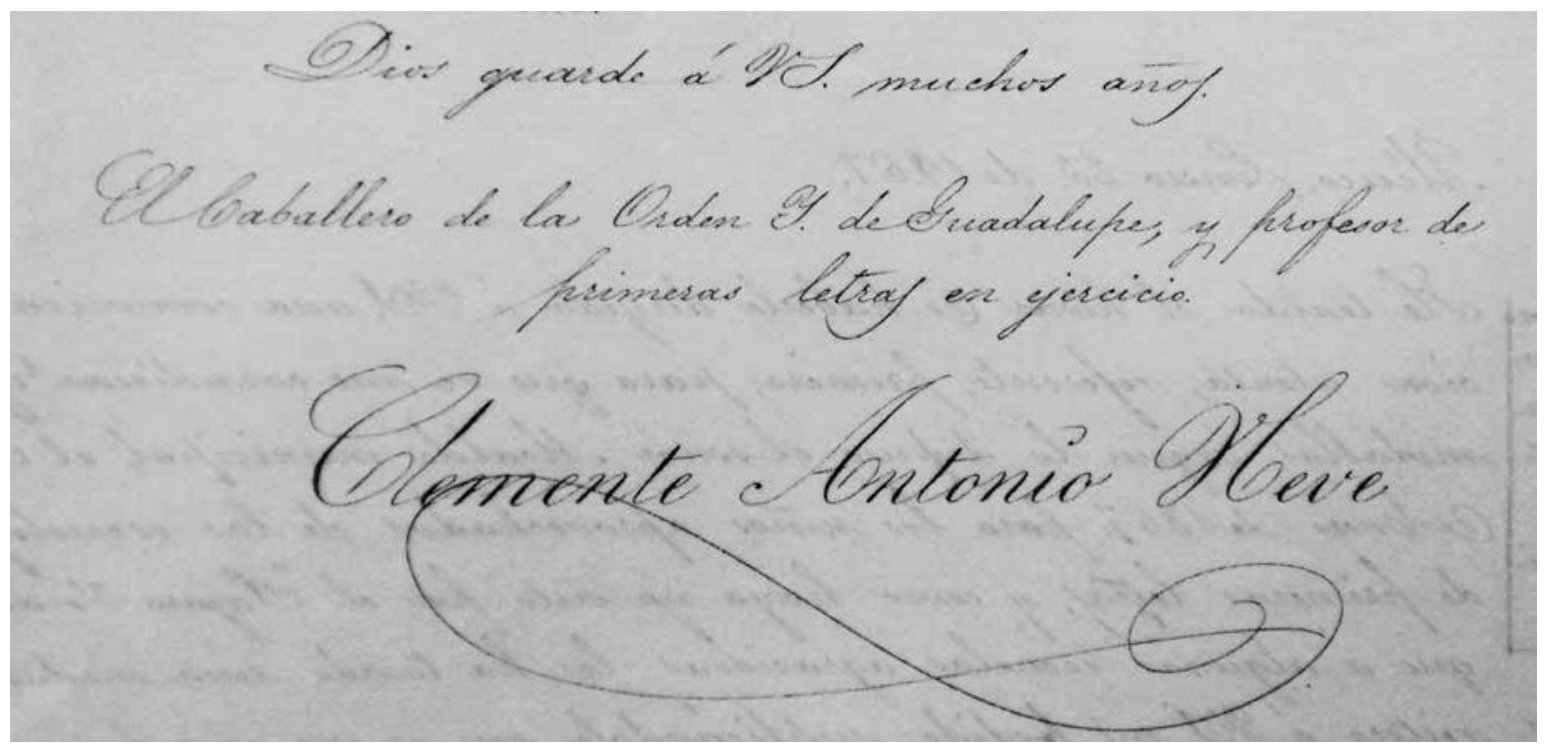

Figura 13. "El caballero de la Orden Imperial de Guadalupe, y profesor de primeras letras en ejercicio Clemente Antonio Neve", Archivo Histórico del Distrito Federal, Fondo Ayuntamiento, Serie Instrucción Pública, vol. 2482, exp. 689, f. 3.

pertenencias se impregnaban del olor característico de la leña, al que se sumaban los producidos por el hacinamiento de una familia numerosa, acumulados debido a la poca o nula ventilación del lugar.

De acuerdo con las crónicas de la época, el deterioro físico de los inmuebles se reflejaba en los vidrios rotos, en el piso de duela enmohecido, en las puertas desvencijadas y las goteras en el techo. ${ }^{21}$ Los 150 habitantes promedio de las viviendas compartían letrinas y lavaderos en los patios (véase la figura 14). ${ }^{22}$ Los espacios domésticos reducidos provocaban que los miembros de las familias convivieran afuera. La gente adulta platicaba y los niños jugaban en los corredores y patios. Como no existía la privacidad, como la conocemos hoy, de esa convivencia podían surgir vínculos amistosos y solidarios (Armendares, 2015: 366-374), pero también chismes y habladurías de unos contra otros, que provocaban disgustos, pleitos y quejas (Cuéllar, 1977: 157-160).

Era frecuente que las personas no pudieran pagar la renta de 15 o 20 pesos durante varios meses, como le sucedió al "pobre profesor", ${ }^{23}$ quien se lamentaba: "no puedo vestir ni pagar la casa que habito". ${ }^{24}$ Los propietarios facultaban a cobradores y porteros para que presionaran a sus inquilinos para que buscaran otro alojamiento. ${ }^{25}$ En la sencilla y "triste habitación" 26 donde vivió, Neve se dio tiempo

$21 \quad$ Véase el estudio sobre las caóticas particularidades de las viviendas de los maestros en Galván (2010: 131-136). Como se puede observar en esta investigación, que corresponde a 1908-1910, las condiciones no habían cambiado.

22 José María Velasco, Patio de San Agustín, 1860, Colección Museo Nacional de Arte, en Artes de México (1964: s/p).

23 Agn, Instrucción Pública y Bellas Artes, 2a. parte, caja 13, exp. 10, ff. 1-5.

24 Carta de Clemente Antonio Neve al emperador Maximiliano, 19 de julio de 1866, AGN, Instrucción Pública y Bellas Artes, 2a. parte, caja 12, exp. 1, f. 1. Otras veces mencionaba que vivía en una "choza".

25 La escritura de múltiples biografías arrojaría datos interesantes acerca de la gran movilidad habitacional de aquellas décadas.

26 Carta de Clemente Antonio Neve al emperador Maximiliano, 19 de julio de 1866, AGN, Instrucción Pública y Bellas Artes, 2a. parte, caja 12, exp. 2, ff. 1-5. 


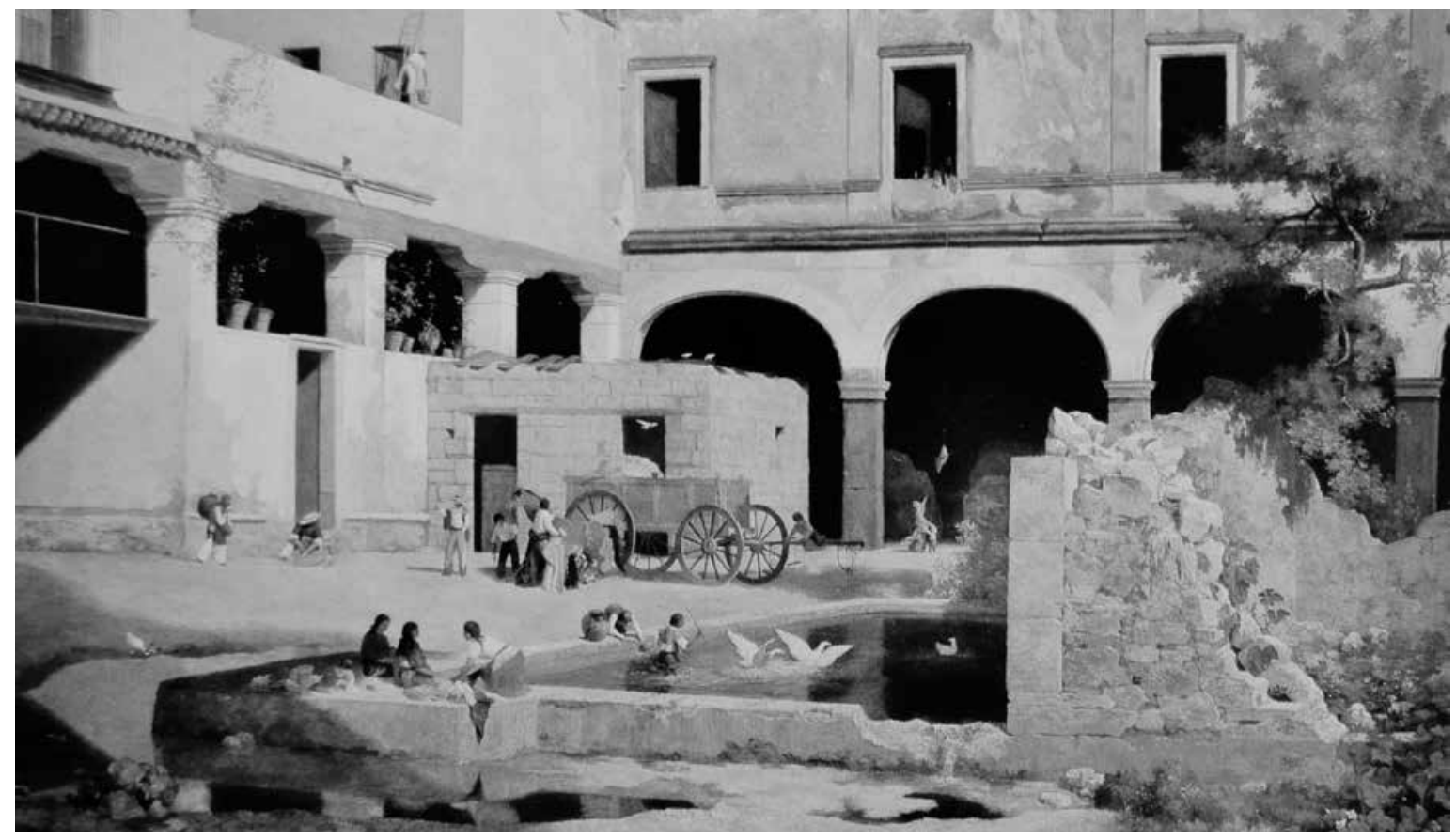

Figura 14. José María Velasco, "Patio del ex convento de San Agustín", 1861.

para escribir alrededor de 15 textos y métodos escolares. Varios maestros escribían manuales, pues esto garantizaba una fuente extra de ingresos, tan necesarios para la supervivencia familiar. Clemente Antonio dijo alguna vez que le tomó seis meses escribir su obra El alumno instruido en la Escuela Elemental de Primera Enseñanza. ${ }^{27}$ Las recomendaciones siempre abrían las puertas, pero al parecer Neve no tenía quien lo recomendara, pese a sus méritos y su medalla. Sin embargo, como nunca se daba por vencido, logró su objetivo de publicar numerosas obras, algunas de ellas novedosas por su creatividad y modernidad pedagógicas.

\section{Conclusiones}

Con la ayuda de múltiples imágenes — mapas, pinturas, litografías, fotografías-, sumadas a la documentación histórica y literaria, he podido reconstruir, con mayor conocimiento, el horizonte social y cultural en el cual vivió el maestro rural Clemente Antonio Neve. La dimensión espacial de Neve, descifrada por medio de la iconografía, resultó esencial para vislumbrar la compleja e inestable atmósfera que respiraba la mayoría de los habitantes de la ciudad de México durante la época del imperio de Maximiliano.

Las imágenes son representaciones de las ideologías de su tiempo y reproducen una simbología, una manera de ver la vida de quien las produce, por ello resulta importante consultar un amplio abanico que ofrezca miradas caleidoscópicas del pasado. Por ejemplo, si nos basáramos en los paisajes campiranos elaborados por Rugendas o Velasco para reconstruir el paisaje rural mexicano, tendríamos una visión idílica — cierta, pero idílica — de la bucólica

Clemente Antonio Neve, El alumno instruido en la Escuela Elemental de Primera Enseñanza, Agn, Instrucción Pública, caja 12, exp. 10. 
naturaleza del siglo XIX. De ahí la importancia de observar otros panoramas en litografías o fotografías que reflejen la otra cara de la historia, la de la suma pobreza de gran parte de la población.

Para acotar el tema del contexto, que parece a nuestros ojos humanos inmenso y disperso, he propuesto, para fines de la construcción biográfica, establecer un área de transición entre la noción de espacio como concepto abstracto y lugar como el sitio específico que se va formando por medio del vínculo con el personaje durante el proceso de investigación. El espacio es un mundo de posibilidades que el biógrafo convierte en lugares específicos. El espacio-lugar, como concepto en el acto biográfico, permite la división de los entornos del biografiado con base en la escala - macro, medio y microy tiene por objetivo ceñirlos a proporciones más manejables, tanto desde la perspectiva visual como desde lo conceptual. De esta forma, conceptualizar el quehacer del biógrafo facilita la metodología, pues en el reino de la imaginación y la percepción parece menos complejo deambular mirando, observando, cual flâneur, en espacios acotados, aunque exista comunión dialéctica entre ellos.

Dado que el objeto de estudio es un docente indígena (1820-1904), el presente trabajo también busca empoderar las pequeñas narrativas a la vez que valida el uso de cultura material para reconstruir la información relevante. La biografía auxiliada por imágenes tiene el potencial historiográfico de observar ciertos detalles que escapan a otros géneros, como los espacios-lugares por los cuales transita el biografiado y que aportan un modelo de experiencia única que permite percibir el pasado con un significado multidimensional, asistido bajo formas escenográficas.D

\section{Bibliografía}

Acevedo, Esther (coord.), 2012, Entre la realidad y la ficción: vida y obra de Maximiliano, Instituto Nacional de Antropología e Historia, México. Aira, César, 2002, Un episodio en la vida del pintor viajero, Lom, Santiago.

Almanaque de la Corte. Año de 1866, 1866, Imprenta del Gabinete Imperial, México.

Amor Schmidtlein, José María, 1978, "Preámbulo”, en Adolfo Schmidtlein, Un médico alemán en el México de Maximiliano. Cartas de Adolfo Schmidtlein a sus padres, 1865-1878, Programas Educativos, México.

Armendares Lozano, Teresa, 2015, "El patio de vecindad como espacio público para la convivencia: ciudad de México, siglo xVIII”, en Pilar Gonzalbo Aizpuru (ed.), Espacios en la historia. Invención y transformación de los espacios sociales, El Colegio de México, México, pp. $361-376$.

Bachelard, Gaston, 1993, La poética del espacio, Fondo de Cultura Económica, México.

Baringo Ezquerra, David, 2013, "La tesis de la producción del espacio en Henri Lefebvre y sus críticos: un enfoque a tomar en consideración", en Quid 16, Revista de Área de Estudios Urbanos, núm. 3, pp. 119-135.

Barros, Cristina y Marco Buenrostro (eds.), 2003, iLas once y serenooo! Tipos mexicanos siglo xIx, Consejo Nacional para la Cultura y las Artes/ Lotería Nacional para la Asistencia Pública/Fondo de Cultura Económica, México.

Blasio, José Luis, 1966, Maximiliano intimo. El emperador Maximiliano y su corte. Memorias de un secretario particular, Editora Nacional, México. Borja Martínez, Ignacio, 2011, Ilustre y distinguida Orden de Nuestra Señora de Guadalupe, Consejo Nacional para la Cultura y las Artes, México.

Burke, Peter, 2005, Visto y no visto. El uso de la imagen como documento histórico, Crítica, Barcelona.

Ciudadanos en Red, 2010, "El antiguo Iztacalco", 21 de octubre, disponible en línea: <http://ciudadanosenred.com.mx/el-antiguo-iztacalco/> Consultado el 1 de abril de 2014

Craib, Raymond B., 2004, Cartographic Mexico. A History of State Fixations and Fugitive Landscapes, Duke University Press, Durham.

Cuartoscuro, 2012, "Chapultepec 'presume' insignias", 13 de junio, disponible en línea: <http://cuartoscuro.com.mx/2012/06/chapultepecpresume-insignias/>.

Cuéllar, Francisca Carlota, 1977, "Casas de vecindad”, en José María Vigil (ed.), Poetisas mexicanas, siglos XVI, XVII, XVIII Y XIX, Universidad Nacional Autónoma de México, México, pp. 157-160. 
Debroise, Oliver, 1989, “José María Velasco y el paisaje fotográfico decimonónico (apuntes para un paralelismo)", en Xavier Moyssén Echeverría et

al., José María Velasco: homenaje, Universidad Nacional Autónoma de México-Instituto de Investigaciones Estéticas, México, pp. 103-122.

Diener, Pablo, 1996, "El perfil del artista”, en Viajeros europeos del siglo xix en México, Fondo Cultural Banamex, México.

Directorio telefónico de la Ciudad de México. Año de 1891, 1979, Centro de Estudios de Historia de México Condumex, México.

Documentos gráficos para la historia de México, 1848-1911, 1985, vol. 1, Editora del Sureste, México.

François, Marie, 2006, "Vivir de prestado. El empeño en la ciudad de México", en Anne Staples (coord.), Historia de la vida cotidiana en México, t. IV: Bienes y vivencias, el siglo xix, El Colegio de México/Fondo de Cultura Económica, México, pp. 81-117.

Galván Lafarga, Luz Elena, 2010, Soledad compartida. Una historia de maestros, 1908-1910, Centro de Investigaciones y Estudios Superiores en Antropología Social, México.

Gandelman, Claude, 1989, “'Scan-paths' in the Paintings of José María Velasco: A Semiotic Approach”, en Xavier Moyssén Echeverría et al., José María Velasco: homenaje, Universidad Nacional Autónoma de México-Instituto de Investigaciones Estéticas, México, pp. 87-102.

Gonzalbo Aizpuru, Pilar, 2006, Introducción a la historia de la vida cotidiana, El Colegio de México, México.

Huizinga, Johan, 1984, El otoño de la Edad Media. Estudios sobre la forma de la vida y del espíritu durante los siglos xIV y xv en Francia y en los Países Bajos, Alianza, Madrid.

Lafragua, José María y Manuel Orozco y Berra, 1998, La ciudad de México, Porrúa (Sepan cuantos..., 520), México.

Latrobe, Charles Joseph, 1836, The Rambler in Mexico, R. B. Seeley and W. Burnside, Londres.

León Toral, Jesús de, 1962, Historia militar. La intervención francesa en México, Sociedad Mexicana de Geografía y Estadística-Primer Congreso Nacional de Historia para el Estudio de la Guerra de Intervención, México.

Lira, Andrés, 1983, Comunidades indigenas frente a la ciudad de México. Tenochtitlan y Tlatelolco, sus pueblos y barrios, 1812-1919, El Colegio de México/El Colegio de Michoacán, Zamora.

Maillefert, Eugenio, 1992, Directorio del comercio del imperio mexicano, Instituto de Investigaciones Dr. José María Luis Mora, México.

Manguel, Alberto, 2002, Leer imágenes. Una historia privada del arte, Alianza, España.

Payno, Manuel, 2001, Los bandidos de Río Frío, Porrúa, México.

Pérez Vejo, Tomás, 2012, “¿Se puede escribir historia a partir de imágenes? El historiador y las fuentes icónicas”, en Memoria y Sociedad, vol. 16, núm. 32, pp. 17-30, disponible en línea: <http://memoriaysociedad.javeriana.edu.co/articulo.php?id=153>.

Rotberg, Robert I. y Theodore K. Rabb (eds.), 1988, Art and History. Images and Their Meaning, Cambridge University Press, Cambridge.

Soja, Edward W., 2009, "Taking Space Personally", en Barney Warf y Santa Arias (eds.), The Spatial Turn. Interdisciplinary Perspectives, Routledge, Nueva York.

Tomàs, Mariona, 2004, "Lo macro, lo mezzo, lo micro", en Café de las Ciudades, año 3, núm. 22, disponible en línea: <http://www.cafedelasciudades.com.ar/politica_22.htm>. Consultado el 26 de agosto de 2015.

Tovar de Teresa, Guillermo, 1990, La Ciudad de los Palacios: crónica de un patrimonio perdido, 2 t., Fundación Cultural Televisa/Vuelta, México. Tuan, Yi-Fu, 2011, Space and Place. The Perspective of Experience, University of Minnesota Press, Minneapolis. , 1990, Topophilia. A Study of Environmental Perception, Attitudes, and Values, Columbia University Press, Nueva York.

Wobeser, Gisela von, 1989, "La pintura paisajista como testimonio de las haciendas en el siglo xIx”, en Xavier Moyssén Echeverría et al., José María Velasco: homenaje, Universidad Nacional Autónoma de México-Instituto de Investigaciones Estéticas, México, pp. 181-202.

\section{Archivos}

Archivo General de la Nación (AGN)

Archivo Histórico del Distrito Federal (AHDF)

Archivo Histórico del Municipio de Naucalpan de Juárez (AHMN)

\section{Hemerografía}

Artes de México, núms. 53-54: La Ciudad de México II, 1964.

Diario del Imperio, 6 de julio de 1866.

La Sociedad, 6 de julio de 1866.

Los Espejuelos del Diablo, 13 y 17 de marzo de 1865. 